\title{
A Global Perspective of Food Market Integration: A Review
}

\section{AGREKON}

Ronald Kabbiri $^{1 \mathrm{a}, \mathrm{b}}$, Manoj Dora ${ }^{\mathrm{c}}$, Gabriel Elepu ${ }^{\mathrm{d}}$, and Xavier Gellynck ${ }^{\mathrm{a}}$

${ }^{a}$ Department of Agricultural Economics, Ghent University, Belgium

${ }^{b}$ Department of Agriculture and Environmental Sciences, Mountains of the Moon University, Uganda

${ }^{c}$ Brunel Business School, Brunel University, London

${ }^{d}$ Department of Agribusiness and Natural Resource Economics, Makerere University, Uganda

${ }^{1}$ Corresponding author: Ronald.Kabbiri@ugent.be 


\begin{abstract}
This paper analyses the state of the art research on food market integration, classifies it and provides a comprehensive bibliography for researchers with interest in market integration. A thorough review of literature published between 1990 and 2014 on food market integration generated 65 articles for in-depth analysis. Findings show that the majority of research has concentrated relatively more on identifying the degree of linkages among the markets but not on its implications. The paper also identifies the following factors as very important in increasing/decreasing the degree of market integration: physical infrastructure, market institutions, information, competition, market power, trade, social capital, public/government intervention and export restrictions/ban. The paper further identifies several areas for future research.
\end{abstract}

Keywords Price co-movement, Co-integration, Price transmission, Commodity markets, Market inter-relationships

\title{
1.0 Introduction
}

Food market integration is a process of market inter-relationships, evidenced by tradability and the resultant co-movements of market prices (Abunyuwah, 2007, Penzhorn and Arndt, 2002). There are mainly two forms of market integration, vertical market integration and spatial market integration (Meyer, 2004). While vertical market integration refers to transmission of price signals from one marketing channel to another, spatial market integration means transmission of price signals between markets in different locations (Minot, 2010). Price transmission, the core of market integration, occurs when a change in one price causes another price to change. Price transmission can either be spatial, vertical or crosscommodity.

Closely related to price transmission is price volatility, which describes how quickly or widely prices can change (Minot, 2010). Price fluctuation is a common feature of wellfunctioning agricultural markets. Nevertheless, when it becomes large and unexpected, i.e. volatile, price fluctuation can have a negative impact on food security of consumers, farmers and the entire population.

The degree of market integration, which is assessed through price transmission and volatility, determines the strength and effectiveness of price mechanism in resource allocation. If food markets are not integrated, price signals will not be transmitted from supply deficit regions to surplus markets. In case prices are volatile, agricultural and food producers will not specialise according to long-run comparative advantage and gains from trade will not be realised (Baulch, 1997a). It is therefore important to understand price transmission and market integration mechanisms in market economies. Further, research on the degree of interdependence and co-integration between food markets around the world helps in improving the decision making techniques and international investor strategies.

While reviewing literature on food market integration, we noticed that earlier studies examined integration among food markets in a linear framework using simple correlation and regression tests as tools for analysis ( $\mathrm{Li}, 2000)$. However, recent studies have applied econometric techniques like co-integration, error correction models, parity bounds model, Johansen co-integration, autoregression, Granger-causality, and Ravallion/Timmer models to test the integration hypothesis (Faminow and Benson, 1990, Badiane and Shively, 1998, Kuiper et al., 1999, Minten and Kyle, 2000, Minten et al., 2014). 
Regarding the location of the studies reviewed, majority of them were conducted in USA, China, Ethiopia and Ghana. Despite majority of them being located in these few countries, the distribution of research in market integration is worldwide. Many countries have been reached. For the countries which have received little or no attention with regard to market integration research, it could be probably because of scarcity of data.

In regard to the number of years considered as sample data, Li (2000) used the biggest sample of 173 years, followed by Marks (2010), who used 58 years. Ghoshray (2011) followed with a sample of 51 years. The rest of the studies used less than 30 years. Regarding the number of countries considered as sample, the majority of studies used only one country. However, Baquedano and Liefert (2014) had 29 countries.

This paper evaluates and systematically arranges past literature by reviewing it thoroughly so that researchers in the area of food market integration can find it useful. Specifically, the study analyses the state of the art research on food market integration, classifies it and provides a perspective for future research. The literature reviewed covers articles on vertical and spatial market integration, symmetric and asymmetric price transmission and price volatility published in high quality journals between 1990 and 2014.

The rest of the paper is structured as follows: section II presents the rationale of the study, section III discusses methodology, section IV presents and discusses results and section V concludes and also suggests questions for further research.

\subsection{Rationale of the study}

Markets are important determinants of food availability and accessibility. The extent to which markets make food available, accessible and keep prices stable depends on whether or not they are integrated. If markets are well-integrated, it is assumed that market forces are working properly, i.e. price changes in location A are consistently related to those in locations B and C. For integrated markets, food will flow from surplus to deficit areas; and imports will flow from port and border areas into the hinterland. High prices in deficit areas provide an incentive to traders to bring food from surplus to deficit areas. As a result, food prices should decline in deficit areas, making it accessible to the majority.

Considering the importance of market integration in the food sector, a lot of research has been done to test integration of food markets all over the world. Some studies found weak or strong integration in food markets whereas others did not find any. Some studies rejected the integration hypothesis and concluded that the food markets they studied were integrated (Abdulai, 2000, Gonzalez-Rivera and Helfand, 2001, García-Enríquez et al., 2014). Other studies, on the other hand, failed to reject the integration hypothesis and concluded that the food markets they studied were not integrated (Gardner and Brooks, 1994, Zhou et al., 2000).

Determinants of market integration are those factors or drivers which may either facilitate or hinder integration of markets (Goletti et al., 1995). Examples of these determinants include physical infrastructure, information, institutions, competition, market power, trade, social capital, government intervention and export restrictions/bans. Several studies have been conducted on how determinants facilitate or hinder market integration (Dercon, 1995, Goletti et al., 1995, Ismet et al., 1998, Loy and Weaver, 1998, Lutz et al., 2006a, Park et al., 2002, Zant, 2012, Cudjoe et al., 2010, Ianchovichina et al., 2014). This paper reviews this literature and identifies questions that require more research. The paper also brings together and analyses various methodologies which have been used in various countries for studying food 
market integration. Finally, several issues that future research on market integration should address are identified in the paper.

\subsection{Methodology}

A total of 65 published articles on market integration in the food sector from various countries all over the world were reviewed. All the reviewed papers were published between 1990 and 2014 in A1 journals. Table 1 shows the basis for classification of the literature, i.e. year, country and source of study, data sample used, methodology adopted and findings and conclusions from the reviewed literature.

The search for literature was based on the keyword descriptor "food or commodity market integration/price transmission/price volatility" for selected databases and websites for a period ranging from 1990 to 2014. We selected the databases for keywords in titles, abstracts, keywords list and full text. The search produced thousands of papers. We then reviewed the full text of the papers, subject to relevance, in order to select the ones related to this study. Based on relevance and consideration of the time period for this study, we finally obtained 65 articles on which we based to write this paper.

We classified the entire literature on food market integration using a systematic model in Figure I (Sharma and Seth, 2012), i.e.

- econometric tools/methodology used in data analysis,

- year of publication,

- country-wise distribution,

- number of years taken as sample dataset,

- number of countries considered for study forming sample data and

- sources of the articles.

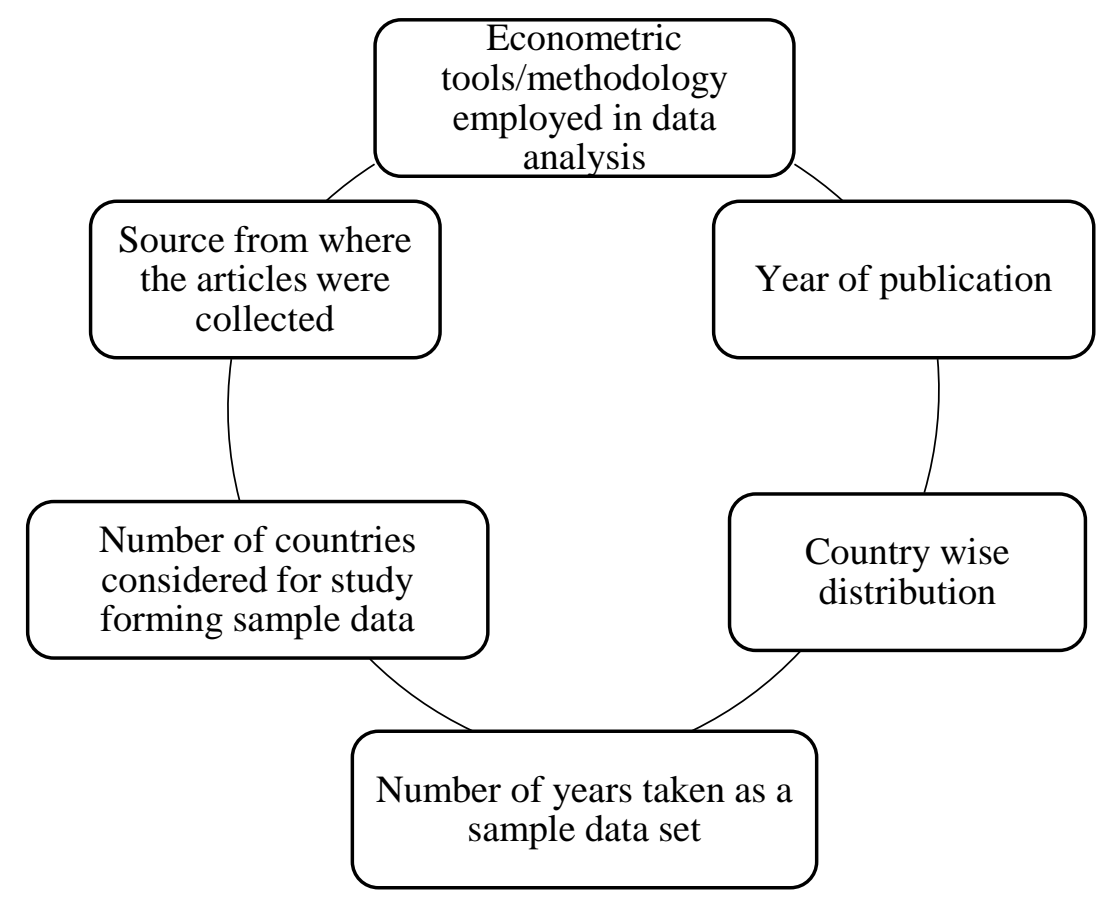

Figure I: Basis for classification of literature on food market integration (modified from Sharma and Seth (2012) 
Table 1: Classification of literature on food market integration

\begin{tabular}{|c|c|c|c|c|c|c|c|c|}
\hline $\begin{array}{l}\text { S. } \\
\text { no }\end{array}$ & $\begin{array}{l}\text { Author(s), } \\
\text { year and } \\
\text { country of } \\
\text { study }\end{array}$ & Title of study & Journal & $\begin{array}{l}\text { Sample } \\
\text { data } \\
\text { (no. of } \\
\text { years) }\end{array}$ & $\begin{array}{l}\text { No. of } \\
\text { sample } \\
\text { countries }\end{array}$ & $\begin{array}{l}\text { Determinants } \\
\text { covered }\end{array}$ & $\begin{array}{l}\text { Methodology } \\
\text { used for data } \\
\text { analysis }\end{array}$ & Findings \& conclusions \\
\hline 1 & $\begin{array}{l}\text { Faminow and } \\
\text { Benson } \\
\text { (1990), } \\
\text { Canada }\end{array}$ & $\begin{array}{l}\text { Integration of spatial } \\
\text { markets }\end{array}$ & $\begin{array}{l}\text { American } \\
\text { Journal of } \\
\text { Agricultural } \\
\text { Economics }\end{array}$ & 11 & 1 & None & Ravallion & $\begin{array}{l}\text { Results suggest non-competitive pricing } \\
\text { system disintegrated during the } 1970-75 \\
\text { period, a time when substantial changes in } \\
\text { the Canadian hog market occurred, and } \\
\text { was replaced by FOB pricing system. The } \\
\text { markets then became integrated. }\end{array}$ \\
\hline 2 & $\begin{array}{l}\text { Dahlgran and } \\
\text { Blank (1992), } \\
\text { USA }\end{array}$ & $\begin{array}{l}\text { Evaluating the } \\
\text { integration of contiguous } \\
\text { discontinuous markets }\end{array}$ & $\begin{array}{l}\text { American } \\
\text { Journal of } \\
\text { Agricultural } \\
\text { Economics }\end{array}$ & 3 & 1 & None & $\begin{array}{l}\text { Vector auto- } \\
\text { regression } \\
\text { (VAR) }\end{array}$ & $\begin{array}{l}\text { Results indicate that continuous markets } \\
\text { were less integrated when discontinuous } \\
\text { markets were operating than when they } \\
\text { were not operating. California-Arizona } \\
\text { alfalfa hay markets were competitive, price } \\
\text { being an important factor in the allocation } \\
\text { process. }\end{array}$ \\
\hline 3 & $\begin{array}{l}\text { Alderman } \\
\text { (1993), Ghana }\end{array}$ & $\begin{array}{l}\text { Inter-commodity price } \\
\text { transmittal: analysis of } \\
\text { food markets in Ghana }\end{array}$ & $\begin{array}{l}\text { Oxford } \\
\text { Bulletin of } \\
\text { Economics } \\
\text { and Statistics }\end{array}$ & 14 & 1 & None & $\begin{array}{l}\text { Ravallion, co- } \\
\text { integration, Gr } \\
\text { anger } \\
\text { causality }\end{array}$ & $\begin{array}{l}\text { Results show that prices of grains in Ghana } \\
\text { were co-integrated. The dynamic model of } \\
\text { price integration indicates functional, if not } \\
\text { perfect, efficiency of Ghanaian coarse } \\
\text { grain markets. }\end{array}$ \\
\hline 4 & $\begin{array}{l}\text { Palaskas and } \\
\text { Harriss-white } \\
\text { (1993), India }\end{array}$ & $\begin{array}{l}\text { Testing market } \\
\text { integration: new } \\
\text { approaches with case } \\
\text { material from the west } \\
\text { Bengal food economy }\end{array}$ & $\begin{array}{l}\text { Journal of } \\
\text { Development } \\
\text { Studies }\end{array}$ & 2 & 1 & None & $\begin{array}{l}\text { Co- } \\
\text { integration, } \\
\text { Autoregressiv } \\
\text { e Conditional } \\
\text { Heteroskedasti } \\
\text { city } \\
\text { (Gluschenko } \\
\text { and } \\
\text { Karchevskaya) }\end{array}$ & $\begin{array}{l}\text { Results suggest that markets were } \\
\text { integrated, but a lower degree of } \\
\text { integration for paddy and rice prices were } \\
\text { identified. Structural and institutional } \\
\text { factors which affect the specifics of } \\
\text { performance were also identified. }\end{array}$ \\
\hline 5 & $\begin{array}{l}\text { Alexander and } \\
\text { Wyeth (1994), } \\
\text { Indonesia }\end{array}$ & $\begin{array}{l}\text { Cointegration and market } \\
\text { integration: an } \\
\text { application to the } \\
\text { Indonesian rice market }\end{array}$ & $\begin{array}{l}\text { Journal of } \\
\text { Development } \\
\text { Studies }\end{array}$ & 12 & 1 & None & Co-integration & $\begin{array}{l}\text { Results confirm that supply sources are } \\
\text { more important than demand sources in } \\
\text { driving prices. The CPI was co-integrated } \\
\text { with all the price series but there was no } \\
\text { great deal of causality from it to the rice }\end{array}$ \\
\hline
\end{tabular}




\begin{tabular}{|c|c|c|c|c|c|c|c|c|}
\hline & & & & & & & & $\begin{array}{l}\text { prices. It did not therefore appear to be the } \\
\text { driving force behind the price changes. }\end{array}$ \\
\hline 6 & $\begin{array}{l}\text { Gardner and } \\
\text { Brooks } \\
\text { (1994), } \\
\text { Russia }\end{array}$ & $\begin{array}{l}\text { Food prices and market } \\
\text { Integration in Russia: } \\
1992-93\end{array}$ & $\begin{array}{l}\text { American } \\
\text { Journal of } \\
\text { Agricultural } \\
\text { Economics }\end{array}$ & 1 & 1 & None & Ravallion & $\begin{array}{l}\text { There was no observable progress toward } \\
\text { market integration during the January } 1992 \\
\text { to April } 1993 \text { period. Therefore, markets } \\
\text { for food stuffs were not integrated during } \\
\text { that period in Russia. }\end{array}$ \\
\hline 7 & $\begin{array}{l}\text { Goletti and } \\
\text { Babu (1994), } \\
\text { Malawi }\end{array}$ & $\begin{array}{l}\text { Market liberalization and } \\
\text { integration of maize } \\
\text { markets in Malawi }\end{array}$ & $\begin{array}{l}\text { Agricultural } \\
\text { Economics }\end{array}$ & 8 & 1 & $\begin{array}{l}\text { Market } \\
\text { liberalisation, } \\
\text { transportation, } \\
\text { communicatio } \\
\text { n, market } \\
\text { power }\end{array}$ & Co-integration & $\begin{array}{l}\text { The study shows that liberalization } \\
\text { enhanced market integration in Malawi. } \\
\text { The private sector has a capacity of } \\
\text { responding to new operating environment } \\
\text { and improving the extent of price } \\
\text { transmission across spatially separated } \\
\text { markets. However, the extent of market } \\
\text { integration was still very low. Market } \\
\text { liberalization by itself cannot achieve a } \\
\text { structural change in market integration } \\
\text { unless investments in marketing } \\
\text { infrastructure (transportation, } \\
\text { communication, etc.) are undertaken. }\end{array}$ \\
\hline 8 & $\begin{array}{l}\text { Dercon } \\
(1995), \\
\text { Ethiopia }\end{array}$ & $\begin{array}{l}\text { On market integration } \\
\text { and liberalisation: } \\
\text { Method and application } \\
\text { to Ethiopia }\end{array}$ & $\begin{array}{l}\text { Journal of } \\
\text { Development } \\
\text { Studies }\end{array}$ & 6 & 1 & $\begin{array}{l}\text { Market } \\
\text { liberalisation }\end{array}$ & Co-integration & $\begin{array}{l}\text { Results from this study show that } \\
\text { liberalisation had important effects on the } \\
\text { long-run and short-run integration of food } \\
\text { markets Ethiopia. Several markets became } \\
\text { integrated with Addis Ababa during the } \\
\text { period of liberalisation. }\end{array}$ \\
\hline 9 & $\begin{array}{l}\text { Fafchamps } \\
\text { and Gavian } \\
(1996), \text { Niger }\end{array}$ & $\begin{array}{l}\text { The spatial integration of } \\
\text { livestock markets in } \\
\text { Niger }\end{array}$ & $\begin{array}{l}\text { Journal of } \\
\text { African } \\
\text { Economies }\end{array}$ & 21 & 1 & None & $\begin{array}{l}\text { Parity bounds } \\
\text { model (PBM) }\end{array}$ & $\begin{array}{l}\text { This article shows that livestock markets in } \\
\text { Niger were poorly integrated. Prices were } \\
\text { seldom co-integrated, suggesting that large } \\
\text { price differentials occasionally persisted } \\
\text { between adjacent areas for long periods of } \\
\text { time. The results confirmed descriptive } \\
\text { studies that had emphasised regional } \\
\text { segmentation in West African livestock } \\
\text { trade. }\end{array}$ \\
\hline 10 & $\begin{array}{l}\text { Palaskas and } \\
\text { Crowe (1996), } \\
\text { UK }\end{array}$ & $\begin{array}{l}\text { Testing for price } \\
\text { transmission with } \\
\text { seasonally integrated } \\
\text { producer and consumer }\end{array}$ & $\begin{array}{l}\text { European } \\
\text { Review of } \\
\text { Agricultural } \\
\text { Economics } \\
\end{array}$ & 20 & 7 & None & Co-integration & $\begin{array}{l}\text { This paper suggests that adequate research } \\
\text { into economic issues such as agricultural } \\
\text { price transmission, the law of one price, } \\
\text { market integration and such like, involving }\end{array}$ \\
\hline
\end{tabular}




\begin{tabular}{|c|c|c|c|c|c|c|c|c|}
\hline & & $\begin{array}{l}\text { price series from } \\
\text { agriculture }\end{array}$ & & & & & & $\begin{array}{l}\text { the use of time-series price data could } \\
\text { utilise more sophisticated techniques to test } \\
\text { for integration and co-integration, given } \\
\text { the often seasonal properties of agricultural } \\
\text { producer price time-series. }\end{array}$ \\
\hline 11 & $\begin{array}{l}\text { Baulch } \\
\text { (1997b), } \\
\text { Philippine }\end{array}$ & $\begin{array}{l}\text { Transfer costs, spatial } \\
\text { arbitrage, and testing for } \\
\text { food market integration }\end{array}$ & $\begin{array}{l}\text { American } \\
\text { Journal of } \\
\text { Agricultural } \\
\text { Economics }\end{array}$ & 14 & 1 & None & PBM & $\begin{array}{l}\text { This paper developed another } \\
\text { methodology, the parity bounds model } \\
\text { (PBM), for testing market integration. It } \\
\text { uses information on transfer costs in } \\
\text { addition to food prices to assess the } \\
\text { efficiency of spatial arbitrage. PBM was } \\
\text { applied to Philippine rice markets and it } \\
\text { detected efficient arbitrage. }\end{array}$ \\
\hline 12 & $\begin{array}{l}\text { Badiane and } \\
\text { Shively } \\
\text { (1998), Ghana }\end{array}$ & $\begin{array}{l}\text { Spatial integration, } \\
\text { transport costs, and the } \\
\text { response of local prices } \\
\text { to policy changes in } \\
\text { Ghana }\end{array}$ & $\begin{array}{l}\text { Journal of } \\
\text { Development } \\
\text { Economics }\end{array}$ & 1 & 1 & $\begin{array}{l}\text { Transport } \\
\text { costs }\end{array}$ & $\begin{array}{l}\text { Timmer, } \\
\text { ARCH }\end{array}$ & $\begin{array}{l}\text { Results show that reductions in local prices } \\
\text { and local price variance following the } \\
\text { introduction of economic reforms in } 1983 \\
\text { could be traced to both local and central } \\
\text { market forces, but that differences in the } \\
\text { degree of market integration had important } \\
\text { implications for long-run changes in } \\
\text { transport costs and the evolution of prices } \\
\text { in outlying markets. }\end{array}$ \\
\hline 13 & $\begin{array}{l}\text { von Cramon- } \\
\text { Taubadel } \\
\text { (1998), } \\
\text { Germany }\end{array}$ & $\begin{array}{l}\text { Estimating asymmetric } \\
\text { price transmission with } \\
\text { the error correction } \\
\text { representation: An } \\
\text { application to the } \\
\text { German pork market }\end{array}$ & $\begin{array}{l}\text { European } \\
\text { Review of } \\
\text { Agricultural } \\
\text { Economics }\end{array}$ & 4 & 1 & None & $\begin{array}{l}\text { Error } \\
\text { correction } \\
\text { representation }\end{array}$ & $\begin{array}{l}\text { The article demonstrates that transmission } \\
\text { between producer and wholesale pork } \\
\text { prices in northern Germany was } \\
\text { asymmetric. In accordance with common } \\
\text { belief, the margin was corrected more } \\
\text { rapidly when it is squeezed relative to its } \\
\text { long-run level, than when it was stretched. }\end{array}$ \\
\hline 14 & $\begin{array}{l}\text { Ismet et al. } \\
\text { (1998), } \\
\text { Indonesia }\end{array}$ & $\begin{array}{l}\text { Government intervention } \\
\text { and market integration in } \\
\text { Indonesian rice markets }\end{array}$ & $\begin{array}{l}\text { Agricultural } \\
\text { Economics }\end{array}$ & 12 & 1 & $\begin{array}{l}\text { Government } \\
\text { intervention }\end{array}$ & $\begin{array}{l}\text { Multivariate } \\
\text { co-integration }\end{array}$ & $\begin{array}{l}\text { Results show that government intervention } \\
\text { in terms of rice procurement significantly } \\
\text { influenced market integration. This } \\
\text { indicates that the aspect of government } \\
\text { intervention had positive influence on } \\
\text { integration, in contrast to distribution } \\
\text { efforts, which were not found to be } \\
\text { statistically significant. Regional per capita } \\
\text { income was also found to be positively } \\
\text { related to higher levels of market }\end{array}$ \\
\hline
\end{tabular}




\begin{tabular}{|c|c|c|c|c|c|c|c|c|}
\hline & & & & & & & & integration. \\
\hline 15 & $\begin{array}{l}\text { Loy and } \\
\text { Weaver } \\
(1998), \text { Russia }\end{array}$ & $\begin{array}{l}\text { Inflation and relative } \\
\text { price volatility in } \\
\text { Russian food markets }\end{array}$ & $\begin{array}{l}\text { European } \\
\text { Review of } \\
\text { Agricultural } \\
\text { Economics }\end{array}$ & 3 & 1 & Inflation & $\begin{array}{l}\text { Multivariate } \\
\text { Generalised } \\
\text { Autoregressiv } \\
\text { e Conditional } \\
\text { Heteroskedacit } \\
\text { y (MGARCH) }\end{array}$ & $\begin{array}{l}\text { Results indicate that distortions in relative } \\
\text { prices were induced by the anticipated } \\
\text { inflation rate, rather than by unanticipated } \\
\text { inflation or a measure of inflation } \\
\text { uncertainty. No support was found for the } \\
\text { Lucas hypothesis that a positive } \\
\text { relationship exists between the relative } \\
\text { price structure and the unanticipated rate of } \\
\text { inflation. }\end{array}$ \\
\hline 16 & $\begin{array}{l}\text { Lutz and } \\
\text { Bassolet } \\
\text { (1999), } \\
\text { Burkina Faso }\end{array}$ & $\begin{array}{l}\text { Information service and } \\
\text { integration of cereal } \\
\text { markets in Burkina Faso }\end{array}$ & $\begin{array}{l}\text { Journal of } \\
\text { African } \\
\text { Economies }\end{array}$ & 3 & 1 & $\begin{array}{l}\text { Information } \\
\text { service }\end{array}$ & Co-integration & $\begin{array}{l}\text { This article shows that impact of diffusion } \\
\text { of prices on market integration was } \\
\text { moderate. In general, market information } \\
\text { service did not have a significant influence } \\
\text { on the integration of cereal markets in } \\
\text { Burkina Faso. }\end{array}$ \\
\hline 17 & $\begin{array}{l}\text { Kuiper et al. } \\
\text { (1999), Benin }\end{array}$ & $\begin{array}{l}\text { Testing for the law of } \\
\text { one price and identifying } \\
\text { price-leading markets: an } \\
\text { application to corn } \\
\text { markets in Benin }\end{array}$ & $\begin{array}{l}\text { Journal of } \\
\text { Regional } \\
\text { Science }\end{array}$ & 2 & 1 & None & $\begin{array}{l}\text { Johansen co- } \\
\text { integration }\end{array}$ & $\begin{array}{l}\text { Although the spatial arbitrage system did } \\
\text { not function for the Benin corn market, it } \\
\text { had a significant time lag for several } \\
\text { marketplaces. This suggests that in } 1988 \text { - } \\
\text { 1989, the sample period, there was scope } \\
\text { for improving the speed of market } \\
\text { adjustment to spatial price differentials. }\end{array}$ \\
\hline 18 & $\begin{array}{l}\text { Minten and } \\
\text { Kyle (1999), } \\
\text { Democratic } \\
\text { Republic of } \\
\text { Congo }\end{array}$ & $\begin{array}{l}\text { The effect of distance } \\
\text { and road quality on food } \\
\text { collection, marketing } \\
\text { margins, and traders' } \\
\text { wages: evidence from } \\
\text { the former Zaire }\end{array}$ & $\begin{array}{l}\text { Journal of } \\
\text { Development } \\
\text { Economics }\end{array}$ & 1 & 1 & $\begin{array}{l}\text { Distance, road } \\
\text { quality }\end{array}$ & $\begin{array}{l}\text { Seemingly } \\
\text { unrelated } \\
\text { regression } \\
\text { estimation } \\
\text { (Goletti and } \\
\text { Babu) }\end{array}$ & $\begin{array}{l}\text { This analysis shows that food price } \\
\text { dispersion was significant both across } \\
\text { products and across regions in former } \\
\text { Zaire. Transportation costs explained most } \\
\text { of the differences in food prices between } \\
\text { producer regions. Road quality was also an } \\
\text { important factor in transportation costs. } \\
\text { However, food prices decreased relatively } \\
\text { faster than transportation costs increased } \\
\text { and traders' wages were higher on bad } \\
\text { roads. }\end{array}$ \\
\hline 19 & $\begin{array}{l}\text { Zanias (1999), } \\
\text { Italy }\end{array}$ & $\begin{array}{l}\text { Seasonality and spatial } \\
\text { integration in agricultural } \\
\text { (product) markets }\end{array}$ & $\begin{array}{l}\text { Agricultural } \\
\text { Economics }\end{array}$ & 17 & 5 & Seasonal roots & Co-integration & $\begin{array}{l}\text { Results show that France and Italy soft } \\
\text { wheat market seemed to be integrated. The } \\
\text { same applied to Belgium, Germany and } \\
\text { UK. There was no indication of market }\end{array}$ \\
\hline
\end{tabular}




\begin{tabular}{|c|c|c|c|c|c|c|c|c|}
\hline & & & & & & & & $\begin{array}{l}\text { integration between the two groups of } \\
\text { countries. The study also found out that the } \\
\text { presence of seasonal unit roots did affect } \\
\text { co-integration. }\end{array}$ \\
\hline 20 & $\begin{array}{l}\text { Abdulai } \\
\text { (2000), Ghana }\end{array}$ & $\begin{array}{l}\text { Spatial price } \\
\text { transmission and } \\
\text { asymmetry in the } \\
\text { Ghanaian maize market }\end{array}$ & $\begin{array}{l}\text { Journal of } \\
\text { Development } \\
\text { Economics }\end{array}$ & 17 & 1 & Market power & $\begin{array}{l}\text { Threshold co- } \\
\text { integration }\end{array}$ & $\begin{array}{l}\text { The findings indicate that major maize } \\
\text { markets in Ghana were well integrated. } \\
\text { Both measures of co-integration revealed } \\
\text { that wholesale maize prices in local } \\
\text { markets responded more swiftly to } \\
\text { increases than to decreases in central } \\
\text { market prices. }\end{array}$ \\
\hline 21 & $\begin{array}{l}\text { Li (2000), } \\
\text { China }\end{array}$ & $\begin{array}{l}\text { Integration and } \\
\text { disintegration in north } \\
\text { china's grain markets, } \\
\text { 1738-1911 }\end{array}$ & $\begin{array}{l}\text { Journal of } \\
\text { Economic } \\
\text { History }\end{array}$ & 173 & 1 & $\begin{array}{l}\text { Trade policies, } \\
\text { physical } \\
\text { infrastructure, } \\
\text { market } \\
\text { infrastructure }\end{array}$ & $\begin{array}{l}\text { Correlation, } \\
\text { coefficients of } \\
\text { variation }\end{array}$ & $\begin{array}{l}\text { The paper demonstrates that while Zhili } \\
\text { (Hebei) province's local grain markets } \\
\text { gradually fragmented, the provincial } \\
\text { market as a whole simultaneously grew } \\
\text { more closely integrated with external } \\
\text { markets, first with Fengtian (Manchuria) } \\
\text { and later with the Lower Yangzi region. } \\
\text { The Qing state's food policies, the } \\
\text { deterioration of transport routes, and the } \\
\text { condition of rural markets provide a } \\
\text { context for understanding these seemingly } \\
\text { paradoxical trends. }\end{array}$ \\
\hline 22 & $\begin{array}{l}\text { Minten and } \\
\text { Kyle (2000), } \\
\text { Democratic } \\
\text { Republic of } \\
\text { Congo }\end{array}$ & $\begin{array}{l}\text { Retail margins, price } \\
\text { transmission and price } \\
\text { asymmetry in urban food } \\
\text { markets: the case of } \\
\text { Kinshasa (Zaire) }\end{array}$ & $\begin{array}{l}\text { Journal of } \\
\text { African } \\
\text { Economies }\end{array}$ & 3 & 1 & $\begin{array}{l}\text { Transaction } \\
\text { costs }\end{array}$ & SURE & $\begin{array}{l}\text { Search, supervision and other difficult-to- } \\
\text { measure transactions costs were more } \\
\text { important in the margin of food products } \\
\text { than measurable marketing costs. Price } \\
\text { transmission between wholesale and retail } \\
\text { happened in the same week. Price } \\
\text { asymmetry was also present for most } \\
\text { products. Products characterised by } \\
\text { relatively more standardisation and } \\
\text { homogeneity were shown to have lower } \\
\text { retail margins and to behave } \\
\text { symmetrically. }\end{array}$ \\
\hline
\end{tabular}




\begin{tabular}{|c|c|c|c|c|c|c|c|c|}
\hline 23 & $\begin{array}{l}\text { Tiffin and } \\
\text { Dawson } \\
\text { (2000), UK }\end{array}$ & $\begin{array}{l}\text { Structural breaks, co- } \\
\text { integration and the farm- } \\
\text { retail price spread for } \\
\text { lamb }\end{array}$ & $\begin{array}{l}\text { Applied } \\
\text { Economics }\end{array}$ & 15 & 1 & None & Co-integration & $\begin{array}{l}\text { Results show that a long-run relationship } \\
\text { existed, and that the direction of Granger- } \\
\text { causality was from retail to producer } \\
\text { prices. Lamb prices were therefore set in } \\
\text { the retail market. Results also show that } \\
\text { there was a structural break in the } \\
\text { relationship in January } 1990 \text { when the } \\
\text { price increased; this coincided exactly with } \\
\text { a change in policy. }\end{array}$ \\
\hline 24 & $\begin{array}{l}\text { Zhou et al. } \\
\text { (2000), China }\end{array}$ & $\begin{array}{l}\text { Integration of rice } \\
\text { markets: the case of } \\
\text { Southern China }\end{array}$ & $\begin{array}{l}\text { Contemporary } \\
\text { Economic } \\
\text { Policy }\end{array}$ & 4 & 1 & $\begin{array}{l}\text { Transport } \\
\text { facilities, } \\
\text { government } \\
\text { intervention, } \\
\text { market } \\
\text { liberalisation }\end{array}$ & Co-integration & $\begin{array}{l}\text { There was lack of integration between the } \\
\text { indica rice markets in China. Poor } \\
\text { transport facilities, government } \\
\text { interventions, and limited amount of grain } \\
\text { available for arbitrage were identified as } \\
\text { major impediments to market integration. } \\
\text { In general, the more liberalized a } \\
\text { marketing system is, the more integrated } \\
\text { the markets are. }\end{array}$ \\
\hline 25 & $\begin{array}{l}\text { Gonzalez- } \\
\text { Rivera and } \\
\text { Helfand } \\
\text { (2001), Brazil }\end{array}$ & $\begin{array}{l}\text { The extent, pattern, and } \\
\text { degree of market } \\
\text { integration: a } \\
\text { multivariate approach for } \\
\text { the Brazilian rice market }\end{array}$ & $\begin{array}{l}\text { American } \\
\text { Journal of } \\
\text { Agricultural } \\
\text { Economics }\end{array}$ & 28 & 1 & $\begin{array}{l}\text { Trade } \\
\text { volumes, } \\
\text { distance, } \\
\text { product } \\
\text { quality }\end{array}$ & $\begin{array}{l}\text { Vector Error } \\
\text { Correction } \\
(\mathrm{VEC})\end{array}$ & $\begin{array}{l}\text { Findings show that large volumes of trade } \\
\text { were not sufficient to generate a high } \\
\text { degree of integration. Among other factors, } \\
\text { it appears that physical distance and } \\
\text { distance in product space (quality) can both } \\
\text { lead to a low degree of integration. }\end{array}$ \\
\hline 26 & $\begin{array}{l}\text { Goodwin and } \\
\text { Piggott } \\
(2001), \text { USA }\end{array}$ & $\begin{array}{l}\text { Spatial market } \\
\text { integration in the } \\
\text { presence of threshold } \\
\text { effects }\end{array}$ & $\begin{array}{l}\text { American } \\
\text { Journal of } \\
\text { Agricultural } \\
\text { Economics }\end{array}$ & 7 & 1 & None & $\begin{array}{l}\text { Threshold } \\
\text { Autoregressio } \\
\text { n (TAR), co- } \\
\text { integration }\end{array}$ & $\begin{array}{l}\text { Results confirmed the presence of } \\
\text { thresholds and indicated strong support for } \\
\text { market integration though adjustments } \\
\text { following shocks may take many days to } \\
\text { complete. Threshold models suggested } \\
\text { much faster adjustments in response to } \\
\text { deviations from equilibrium than was the } \\
\text { case when threshold behaviour was } \\
\text { ignored. }\end{array}$ \\
\hline 27 & $\begin{array}{l}\text { Lloyd et al. } \\
\text { (2001), UK }\end{array}$ & $\begin{array}{l}\text { The impact of food } \\
\text { scares on price } \\
\text { adjustment in the UK } \\
\text { beef market }\end{array}$ & $\begin{array}{l}\text { Agricultural } \\
\text { Economics }\end{array}$ & 9 & 1 & Market power & Co-integration & $\begin{array}{l}\text { Results demonstrated that market power } \\
\text { exacerbates price changes in the upstream } \\
\text { sectors for a given change in the retail } \\
\text { demand function. The implication of those } \\
\text { varying price changes was that food safety } \\
\text { concerns also cause marketing margins }\end{array}$ \\
\hline
\end{tabular}




\begin{tabular}{|c|c|c|c|c|c|c|c|c|}
\hline & & & & & & & & between the stages to widen. \\
\hline 28 & $\begin{array}{l}\text { Barrett and Li } \\
\text { (2002), USA }\end{array}$ & $\begin{array}{l}\text { Distinguishing between } \\
\text { equilibrium and } \\
\text { integration in spatial } \\
\text { price analysis }\end{array}$ & $\begin{array}{l}\text { American } \\
\text { Journal of } \\
\text { Agricultural } \\
\text { Economics }\end{array}$ & 7 & 4 & None & $\begin{array}{l}\text { Extended } \\
\text { PBM }\end{array}$ & $\begin{array}{l}\text { The study found competitive equilibrium } \\
\text { and tradability to prevail in Pacific soybean } \\
\text { meal markets even though trade flows were } \\
\text { intermittent at monthly frequency on most } \\
\text { international routes. After distinguishing } \\
\text { between competitive spatial equilibrium } \\
\text { and integration, it was apparent that Pacific } \\
\text { soybean meal markets were functioning } \\
\text { well. }\end{array}$ \\
\hline 29 & $\begin{array}{l}\text { Park et al. } \\
(2002) \text {, } \\
\text { China }\end{array}$ & $\begin{array}{l}\text { Market emergence and } \\
\text { transition: arbitrage, } \\
\text { transaction costs, and } \\
\text { autarky in China's grain } \\
\text { markets }\end{array}$ & $\begin{array}{l}\text { American } \\
\text { Journal of } \\
\text { Agricultural } \\
\text { Economics }\end{array}$ & 8 & 1 & $\begin{array}{l}\text { Trade } \\
\text { restrictions, } \\
\text { trade policies, } \\
\text { physical } \\
\text { infrastructure }\end{array}$ & PBM & $\begin{array}{l}\text { According to this paper, trade restrictions } \\
\text { could not explain the pattern of uneven } \\
\text { market development over time. } \\
\text { Infrastructure bottlenecks, managerial } \\
\text { incentive reforms, and production } \\
\text { specialisation policies, all were likely } \\
\text { important factors affecting market } \\
\text { performance. }\end{array}$ \\
\hline 30 & $\begin{array}{l}\text { Thompson et } \\
\text { al. (2002), } \\
\text { Germany }\end{array}$ & $\begin{array}{l}\text { Spatial market efficiency } \\
\text { and policy regime } \\
\text { change: seemingly } \\
\text { unrelated error correction } \\
\text { model estimation }\end{array}$ & $\begin{array}{l}\text { American } \\
\text { Journal of } \\
\text { Agricultural } \\
\text { Economics }\end{array}$ & 24 & 3 & $\begin{array}{l}\text { Market } \\
\text { liberalization }\end{array}$ & $\begin{array}{l}\text { Seemingly } \\
\text { unrelated } \\
\text { regression- } \\
\text { augmented } \\
\text { Dickey-Fuller } \\
\text { (SURADF), } \\
\text { Error } \\
\text { Correction } \\
\text { Model (ECM) } \\
\end{array}$ & $\begin{array}{l}\text { The paper argues that SURADF is more } \\
\text { efficient than ordinary co-integration and } \\
\text { error correction models. Empirically a } \\
\text { strong evidence of efficient spatial markets } \\
\text { and conformity to the law of one price was } \\
\text { found. Market liberalization reforms in the } \\
\text { EU increased the co-movement of } \\
\text { domestic and world wheat prices. }\end{array}$ \\
\hline 31 & $\begin{array}{l}\text { Rashid (2004), } \\
\text { Uganda }\end{array}$ & $\begin{array}{l}\text { Spatial integration of } \\
\text { maize markets in post- } \\
\text { liberalized Uganda }\end{array}$ & $\begin{array}{l}\text { Journal of } \\
\text { African } \\
\text { Economies }\end{array}$ & 3 & 1 & $\begin{array}{l}\text { Market } \\
\text { liberalization }\end{array}$ & $\begin{array}{l}\text { Co- } \\
\text { integration, } \\
\text { VAR }\end{array}$ & $\begin{array}{l}\text { Results show that there was an overall } \\
\text { improvement in spatial price } \\
\text { responsiveness in maize markets in } \\
\text { Uganda although the northern districts } \\
\text { continued to lack integration with major } \\
\text { consumption markets in the central region. } \\
\text { Compared to the 1993-1994-time period, } \\
\text { representing the early years of } \\
\text { liberalization, interdependence among } \\
\text { markets increased. }\end{array}$ \\
\hline
\end{tabular}




\begin{tabular}{|c|c|c|c|c|c|c|c|c|}
\hline 32 & $\begin{array}{l}\text { Araujo (2005), } \\
\text { Burkina Faso }\end{array}$ & $\begin{array}{l}\text { Devaluation and cattle } \\
\text { markets integration in } \\
\text { Burkina Faso }\end{array}$ & $\begin{array}{l}\text { Journal of } \\
\text { African } \\
\text { Economies }\end{array}$ & 7 & 1 & None & $\begin{array}{l}\text { Switching } \\
\text { regime } \\
\text { regression }\end{array}$ & $\begin{array}{l}\text { The theoretical model and econometric } \\
\text { results in this study highlight a positive } \\
\text { impact of the CFA franc devaluation. It } \\
\text { favoured local cattle market integration } \\
\text { through an increase in the marginal trade } \\
\text { profit. Indeed, the devaluation induced a } \\
\text { more significant rise in cattle prices than in } \\
\text { transaction costs which mainly consist of } \\
\text { non-tradable goods and services such as } \\
\text { labour. This effect simply results from the } \\
\text { real exchange rate depreciation that } \\
\text { follows the nominal devaluation and from } \\
\text { the predominance of labour-intensive } \\
\text { transaction costs within the country. }\end{array}$ \\
\hline 33 & $\begin{array}{l}\text { Bojnec and } \\
\text { Peter (2005), } \\
\text { Slovenia }\end{array}$ & $\begin{array}{l}\text { Vertical market } \\
\text { integration and } \\
\text { competition: the meat } \\
\text { sector in Slovenia }\end{array}$ & $\begin{array}{l}\text { Agricultural } \\
\text { and food } \\
\text { science }\end{array}$ & 11 & 1 & None & Co-integration & $\begin{array}{l}\text { Results from this paper confirmed the } \\
\text { existence of long run market integration in } \\
\text { the meat chain and the speed of adjustment } \\
\text { of price changes. Farm-gate meat prices } \\
\text { were identified as weakly exogenous, } \\
\text { indicating the crucial role of supply side } \\
\text { processing and marketing factors in the } \\
\text { retail meat price determination. The } \\
\text { increased competitive market pressures are } \\
\text { very likely to increase efficiency in the } \\
\text { beef markets. Efficiency improvements in } \\
\text { the Slovenian food markets are needed in } \\
\text { the increased competitive market pressures } \\
\text { of the enlarged EU markets. }\end{array}$ \\
\hline 34 & $\begin{array}{l}\text { Getnet et al. } \\
(2005), \\
\text { Ethiopia }\end{array}$ & $\begin{array}{l}\text { Modelling spatial price } \\
\text { transmission in the grain } \\
\text { markets of Ethiopia with } \\
\text { an application of ARDL } \\
\text { approach to white teff }\end{array}$ & $\begin{array}{l}\text { Agricultural } \\
\text { Economics }\end{array}$ & 1 & 5 & $\begin{array}{l}\text { Government } \\
\text { intervention }\end{array}$ & $\begin{array}{l}\text { Autoregressiv } \\
\text { e distributed } \\
\text { lag ( ARDL), } \\
\text { co-integration }\end{array}$ & $\begin{array}{l}\text { The results reveal that the wholesale price } \\
\text { of white teff in the central consumer } \\
\text { market was a major short- and long-run } \\
\text { determinant of the producer price in the } \\
\text { local supply markets. Therefore, the } \\
\text { institutional role of government with the } \\
\text { aim of improving producers' marketing } \\
\text { margin and the overall performance of the } \\
\text { grain markets in the post-liberalization } \\
\text { period could be influenced through } \\
\text { targeted interventions at the central }\end{array}$ \\
\hline
\end{tabular}




\begin{tabular}{|c|c|c|c|c|c|c|c|c|}
\hline & & & & & & & & wholesale market. \\
\hline 35 & $\begin{array}{l}\text { Lutz et al. } \\
\text { (2006b), } \\
\text { Vietnam }\end{array}$ & $\begin{array}{l}\text { Rice market integration } \\
\text { in the Mekong River } \\
\text { Delta1 }\end{array}$ & $\begin{array}{l}\text { Economics of } \\
\text { Transition }\end{array}$ & 4 & 1 & None & $\begin{array}{l}\text { Vector Error } \\
\text { Correction } \\
\text { (VECM) }\end{array}$ & $\begin{array}{l}\text { The results show that price patterns } \\
\text { correlated strongly in the Mekong River } \\
\text { Delta. Even prices in other regions were } \\
\text { integrated with price patterns in the South. } \\
\text { Private traders in the Mekong Delta were } \\
\text { only indirectly responsible for the latter } \\
\text { result. In the framework of the national } \\
\text { food security policy, the state-owned food } \\
\text { companies 'subsidized' transactions } \\
\text { between the South and the North. } \\
\text { Moreover, the state-owned food companies } \\
\text { still dominated export transactions. }\end{array}$ \\
\hline 36 & $\begin{array}{l}\text { Lutz et al. } \\
\text { (2006a), Benin }\end{array}$ & $\begin{array}{l}\text { Maize market } \\
\text { liberalisation in Benin: a } \\
\text { case of hysteresis }\end{array}$ & $\begin{array}{l}\text { Journal of } \\
\text { African } \\
\text { Economies }\end{array}$ & 15 & 1 & $\begin{array}{l}\text { Market } \\
\text { liberalisation }\end{array}$ & Co-integration & $\begin{array}{l}\text { According to this article, the liberalisation } \\
\text { policies in Benin did not significantly } \\
\text { affect maize market integration. Therefore, } \\
\text { more effective policy instruments were } \\
\text { required in order to strengthen the } \\
\text { competitive forces in the market. }\end{array}$ \\
\hline 37 & $\begin{array}{l}\text { Asche et al. } \\
\text { (2007), } \\
\text { Norway }\end{array}$ & $\begin{array}{l}\text { Price transmission and } \\
\text { market integration: } \\
\text { vertical and horizontal } \\
\text { price linkages for salmon }\end{array}$ & $\begin{array}{l}\text { Applied } \\
\text { Economics }\end{array}$ & 7 & 3 & None & $\begin{array}{l}\text { Co- } \\
\text { integration, } \\
\text { VAR, } \\
\text { ECM }\end{array}$ & $\begin{array}{l}\text { The study found a high degree of price } \\
\text { transmission and market integration in both } \\
\text { supply chains for salmon produced in } \\
\text { Norway and UK and then sold at retail } \\
\text { level in France as smoked salmon. While } \\
\text { Norwegian and UK salmon obviously do } \\
\text { not compete at the producer level, the high } \\
\text { degree of price transmission gives the close } \\
\text { link through the competition at the export } \\
\text { level. This implies that measures at any } \\
\text { point in the supply chain are to a large } \\
\text { extent transmitted to the producer prices } \\
\text { and that all measures that restrict } \\
\text { Norwegian production or market access } \\
\text { will be highly beneficial for UK producers. }\end{array}$ \\
\hline 38 & $\begin{array}{l}\text { Awokuse } \\
\text { (2007), } \\
\text { China }\end{array}$ & $\begin{array}{l}\text { Market reforms, spatial } \\
\text { price dynamics, and } \\
\text { China's rice market } \\
\text { integration: a causal }\end{array}$ & $\begin{array}{l}\text { Journal of } \\
\text { Agricultural } \\
\text { and Resource } \\
\text { Economics }\end{array}$ & 1 & 10 & $\begin{array}{l}\text { Market } \\
\text { reforms }\end{array}$ & $\begin{array}{l}\text { Co- } \\
\text { integration, } \\
\text { directed } \\
\text { acyclic graphs }\end{array}$ & $\begin{array}{l}\text { While empirical results confirm existence } \\
\text { of strong market linkages subsequent to the } \\
\text { reforms of the early } 1990 \text { s, the linkages } \\
\text { became less as the Chinese government }\end{array}$ \\
\hline
\end{tabular}




\begin{tabular}{|c|c|c|c|c|c|c|c|c|}
\hline & & $\begin{array}{l}\text { analysis with directed } \\
\text { acyclic graphs }\end{array}$ & & & & & & $\begin{array}{l}\text { reversed several reform policies in the mid- } \\
\text { 1990s. Overall, the empirical evidence } \\
\text { from this study indicates that China's } \\
\text { agricultural market policy reforms have } \\
\text { been relatively effective. }\end{array}$ \\
\hline 40 & $\begin{array}{l}\text { Van } \\
\text { Campenhout } \\
(2007), \\
\text { Tanzania }\end{array}$ & $\begin{array}{l}\text { Modelling trends in food } \\
\text { market integration: } \\
\text { method and an } \\
\text { application to Tanzanian } \\
\text { maize markets }\end{array}$ & Food Policy & 12 & 1 & $\begin{array}{l}\text { Transaction } \\
\text { costs }\end{array}$ & PBM, TAR & $\begin{array}{l}\text { For all six market pairs considered in this } \\
\text { study, transaction costs decreased over } \\
\text { time. More specifically for Tanzania, this } \\
\text { study has the potential to help government } \\
\text { officials in their efforts to increase market } \\
\text { performance in order to maintain food } \\
\text { security. }\end{array}$ \\
\hline 41 & $\begin{array}{l}\text { Baulch et al. } \\
\text { (2008), } \\
\text { Vietnam }\end{array}$ & $\begin{array}{l}\text { The spatial integration of } \\
\text { paddy markets in } \\
\text { Vietnam }\end{array}$ & $\begin{array}{l}\text { Journal of } \\
\text { Agricultural } \\
\text { Economics }\end{array}$ & 14 & 1 & $\begin{array}{l}\text { Market } \\
\text { policies }\end{array}$ & Ravallion & $\begin{array}{l}\text { There was evidence of both threshold } \\
\text { effects and stronger market integration } \\
\text { within the Red and Mekong River deltas. } \\
\text { These results suggest that national level } \\
\text { policies cannot be relied upon to stabilise } \\
\text { or support paddy prices in Vietnam. }\end{array}$ \\
\hline 42 & \begin{tabular}{|l} 
Cirera and \\
Arndt (2008), \\
Mozambique
\end{tabular} & $\begin{array}{l}\text { Measuring the impact of } \\
\text { road rehabilitation on } \\
\text { spatial market efficiency } \\
\text { in maize markets in } \\
\text { Mozambique }\end{array}$ & $\begin{array}{l}\text { Agricultural } \\
\text { Economics }\end{array}$ & 1 & 6 & $\begin{array}{l}\text { Fuel prices, } \\
\text { transaction } \\
\text { costs, road } \\
\text { rehabilitation }\end{array}$ & PBM & $\begin{array}{l}\text { While results point broadly toward a } \\
\text { positive impact of road rehabilitation on } \\
\text { spatial efficiency, they were not as robust } \\
\text { as one would have liked. Large increases in } \\
\text { fuel prices likely offset the positive } \\
\text { impacts of road rehabilitation on } \\
\text { transaction costs, contributing to the }\end{array}$ \\
\hline
\end{tabular}




\begin{tabular}{|c|c|c|c|c|c|c|c|c|}
\hline & & & & & & & & $\begin{array}{l}\text { increase in the probability of being in an } \\
\text { autarky regime. }\end{array}$ \\
\hline 43 & $\begin{array}{l}\text { Brummer et al. } \\
\text { (2009), } \\
\text { Ukraine }\end{array}$ & $\begin{array}{l}\text { The impact of market } \\
\text { and policy instability on } \\
\text { price transmission } \\
\text { between wheat and flour } \\
\text { in Ukraine }\end{array}$ & $\begin{array}{l}\text { European } \\
\text { Review of } \\
\text { Agricultural } \\
\text { Economics }\end{array}$ & 5 & 1 & $\begin{array}{l}\text { Market } \\
\text { reforms }\end{array}$ & $\begin{array}{l}\text { Markov- } \\
\text { switching } \\
\text { VECM }\end{array}$ & $\begin{array}{l}\text { The analysis reveals four regimes whose } \\
\text { timing coincided with political and } \\
\text { economic events in Ukraine. Strong } \\
\text { coincidence between a 'high uncertainty' } \\
\text { regime and discretionary policy } \\
\text { interventions suggests that policy } \\
\text { responses to fluctuations in Ukrainian } \\
\text { harvests may have amplified instability. }\end{array}$ \\
\hline 44 & $\begin{array}{l}\text { Coleman } \\
\text { (2009), USA }\end{array}$ & $\begin{array}{l}\text { Storage, slow transport, } \\
\text { and the law of one price: } \\
\text { theory with evidence } \\
\text { from nineteenth-century } \\
\text { U.S. corn markets }\end{array}$ & $\begin{array}{l}\text { Review of } \\
\text { Economics } \\
\text { and Statistics }\end{array}$ & 14 & 1 & $\begin{array}{l}\text { Inventory } \\
\text { management, } \\
\text { transaction } \\
\text { costs, } \\
\text { transport costs }\end{array}$ & $\begin{array}{l}\text { Threshold } \\
\text { regression }\end{array}$ & $\begin{array}{l}\text { This paper argues that localised price } \\
\text { spikes should be a regular feature of } \\
\text { competitive commodity markets. It } \\
\text { develops a rational expectations model of } \\
\text { physical arbitrage in which trade takes time } \\
\text { and shows that inventory management } \\
\text { plays a crucial role in the way regional } \\
\text { prices are determined. }\end{array}$ \\
\hline 45 & $\begin{array}{l}\text { Moser et al. } \\
\text { (2009), } \\
\text { Madagascar }\end{array}$ & $\begin{array}{l}\text { Spatial integration at } \\
\text { multiple scales: rice } \\
\text { markets in Madagascar }\end{array}$ & $\begin{array}{l}\text { Agricultural } \\
\text { Economics }\end{array}$ & 1 & 1 & $\begin{array}{l}\text { Market } \\
\text { institutions, } \\
\text { physical } \\
\text { infrastructure }\end{array}$ & PBM & $\begin{array}{l}\text { This study shows that Malagasy rice } \\
\text { markets are fairly well integrated spatially } \\
\text { at the sub regional level. Even without } \\
\text { significant public provision of supporting } \\
\text { institutional or physical infrastructure, } \\
\text { local-level trade appears to operate in an } \\
\text { efficient, competitive manner in the vast } \\
\text { majority of places and periods. By contrast, } \\
\text { markets at national and regional } \\
\text { (provincial) levels are far less commonly in } \\
\text { competitive tradable equilibrium. }\end{array}$ \\
\hline 46 & $\begin{array}{l}\text { Cudjoe et al. } \\
\text { (2010), Ghana }\end{array}$ & $\begin{array}{l}\text { Local impacts of a global } \\
\text { crisis: food price } \\
\text { transmission, consumer } \\
\text { welfare and poverty in } \\
\text { Ghana }\end{array}$ & Food Policy & 2 & 1 & Distance & $\begin{array}{l}\text { Threshold co- } \\
\text { integration }\end{array}$ & $\begin{array}{l}\text { This paper shows that prices for domestic } \\
\text { grain products were highly correlated with } \\
\text { world market prices. Price transmission } \\
\text { was high between regional producer } \\
\text { markets and markets located in the } \\
\text { country's largest cities. The distance } \\
\text { between producer and consumer markets } \\
\text { and the size of consumer markets } \\
\text { explained the price transmission. It was } \\
\text { further noted that the poorest of the poor }\end{array}$ \\
\hline
\end{tabular}




\begin{tabular}{|c|c|c|c|c|c|c|c|c|}
\hline & & & & & & & & $\begin{array}{l}\text { were hardest hit by high food prices. The } \\
\text { negative effect of the food crisis was } \\
\text { particularly strong in northern Ghana. }\end{array}$ \\
\hline 47 & $\begin{array}{l}\text { Ge et al. } \\
\text { (2010), China }\end{array}$ & $\begin{array}{l}\text { Cotton market } \\
\text { integration and the } \\
\text { impact of China's new } \\
\text { exchange rate regime }\end{array}$ & $\begin{array}{l}\text { Agricultural } \\
\text { Economics }\end{array}$ & 5 & 2 & $\begin{array}{l}\text { Exchange rate, } \\
\text { market } \\
\text { liberalisation }\end{array}$ & $\mathrm{ARCH}$ & $\begin{array}{l}\text { The study found a long-run co-integration } \\
\text { relationship that exists between } \\
\text { Intercontinental Exchange in the U.S. and } \\
\text { the Zhengzhou Commodity Exchange in } \\
\text { China. The two markets share price } \\
\text { transmissions. This paper argues that } \\
\text { China's recent exchange rate reform and its } \\
\text { gradual liberalisation in bilateral cotton } \\
\text { trade since it joined World Trade } \\
\text { Organization have had important impacts } \\
\text { on the futures market. }\end{array}$ \\
\hline 48 & $\begin{array}{l}\text { Marks (2010), } \\
\text { Indonesia }\end{array}$ & $\begin{array}{l}\text { Unity or diversity? On } \\
\text { the integration and } \\
\text { efficiency of rice } \\
\text { markets in Indonesia, c. } \\
\text { 1920-2006 }\end{array}$ & $\begin{array}{l}\text { Explorations } \\
\text { in Economic } \\
\text { History }\end{array}$ & 58 & 1 & None & $\begin{array}{l}\text { Coefficient of } \\
\text { variation } \\
(\mathrm{CV}) \text {, co- } \\
\text { integration }\end{array}$ & $\begin{array}{l}\text { The paper shows that during Indonesia's } \\
\text { colonial period, rice markets were } \\
\text { relatively well integrated and functioned } \\
\text { efficiently. However, the Second World } \\
\text { War and the subsequent struggle for } \\
\text { independence resulted in disintegrated and } \\
\text { inefficient markets. It was in the late } 1970 \text { s } \\
\text { that markets in Indonesia returned to a } \\
\text { situation which could be spoken of as a } \\
\text { national integrated economy with well- } \\
\text { functioning markets. }\end{array}$ \\
\hline 49 & $\begin{array}{l}\text { Sanogo and } \\
\text { Maliki } \\
\text { Amadou } \\
(2010), \text { Nepal }\end{array}$ & $\begin{array}{l}\text { Rice market integration } \\
\text { and food security in } \\
\text { Nepal: the role of cross- } \\
\text { border trade with India }\end{array}$ & Food Policy & 6 & 1 & None & TAR & $\begin{array}{l}\text { Results show that price response behaviour } \\
\text { of traders was consistent with an } \\
\text { asymmetric price adjustment mechanism, } \\
\text { indicating coarse rice prices in Nepal } \\
\text { responded to shocks originating in India. } \\
\text { Adjustments to negative price deviations } \\
\text { from long-run stable equilibrium were also } \\
\text { faster than adjustments to the positive ones } \\
\text { given a null threshold. }\end{array}$ \\
\hline 50 & $\begin{array}{l}\text { Iregui and } \\
\text { Otero (2010), } \\
\text { Colombia }\end{array}$ & $\begin{array}{l}\text { Testing the law of one } \\
\text { price in food markets: } \\
\text { evidence for Colombia } \\
\text { using disaggregated data }\end{array}$ & $\begin{array}{l}\text { Empirical } \\
\text { Economics }\end{array}$ & 9 & 1 & None & $\begin{array}{l}\text { Kwiatkowski- } \\
\text { Phillips-- } \\
\text { Schmidt-Shin } \\
\text { tests (KPSS), } \\
\text { Hadri tests, }\end{array}$ & $\begin{array}{l}\text { This study suggests that market integration } \\
\text { is favoured by similarities in terms of both } \\
\text { population and economic sizes. The study } \\
\text { also found out that the rate of convergence } \\
\text { of price differentials to exogenous shocks }\end{array}$ \\
\hline
\end{tabular}




\begin{tabular}{|c|c|c|c|c|c|c|c|c|}
\hline & & & & & & & VAR & $\begin{array}{l}\text { or innovations, in a context in which trade } \\
\text { barriers and exchange rate volatility are } \\
\text { absent, is much faster the more perishable } \\
\text { a food product is. }\end{array}$ \\
\hline 51 & $\begin{array}{l}\text { Serra et al. } \\
(2010) \\
\text { Brazil }\end{array}$ & $\begin{array}{l}\text { Price volatility in ethanol } \\
\text { markets }\end{array}$ & $\begin{array}{l}\text { European } \\
\text { Review of } \\
\text { Agricultural } \\
\text { Economics }\end{array}$ & 8 & 1 & None & $\begin{array}{l}\text { Co- } \\
\text { integration, } \\
\text { MGARCH }\end{array}$ & $\begin{array}{l}\text { Results show that ethanol producers } \\
\text { consider crude oil as a substitute and, } \\
\text { consequently, transmit the inflation } \\
\text { originating in the crude oil market to the } \\
\text { Brazilian renewable fuels market. } \\
\text { Increases in sugar prices were also found } \\
\text { to increase ethanol price levels and } \\
\text { volatility. Given that ethanol markets have } \\
\text { strengthened the link between food and } \\
\text { energy markets, both sugar and oil prices } \\
\text { were found to respond to changes in the } \\
\text { other prices in the model. }\end{array}$ \\
\hline 52 & $\begin{array}{l}\text { Baquedano et } \\
\text { al. (2011), } \\
\text { Mali and } \\
\text { Nicaragua }\end{array}$ & $\begin{array}{l}\text { World market integration } \\
\text { for export and food crops } \\
\text { in developing countries: } \\
\text { a case study for Mali and } \\
\text { Nicaragua }\end{array}$ & $\begin{array}{l}\text { Agricultural } \\
\text { Economics }\end{array}$ & 10 & 2 & None & $\begin{array}{l}\text { Generalized } \\
\text { ECM }\end{array}$ & $\begin{array}{l}\text { Results show that for both its main export } \\
\text { and import commodity, Nicaragua is more } \\
\text { integrated into world markets and has } \\
\text { higher price transmission than Mali. The } \\
\text { results for Nicaragua also show much } \\
\text { higher integration and price transmission } \\
\text { for its main agricultural export (coffee) } \\
\text { than its major import (rice). }\end{array}$ \\
\hline 53 & $\begin{array}{l}\text { Ghoshray and } \\
\text { Ghosh (2011), } \\
\text { India }\end{array}$ & $\begin{array}{l}\text { How integrated is the } \\
\text { Indian wheat market? }\end{array}$ & $\begin{array}{l}\text { Journal of } \\
\text { Development } \\
\text { Studies }\end{array}$ & 19 & 1 & $\begin{array}{l}\text { Transaction } \\
\text { costs, } \\
\text { information } \\
\text { services }\end{array}$ & $\begin{array}{l}\text { Multivariate- } \\
\text { TAR }\end{array}$ & $\begin{array}{l}\text { Results indicate that wheat price signals } \\
\text { within states were transmitted over time in } \\
\text { an asymmetric manner. This type of price } \\
\text { adjusting behaviour was consistent as to } \\
\text { how price differentials may respond to } \\
\text { poor dissemination of knowledge } \\
\text { regarding market conditions and high } \\
\text { transactions costs. }\end{array}$ \\
\hline 54 & $\begin{array}{l}\text { Serra et al. } \\
(2011), \text { USA }\end{array}$ & $\begin{array}{l}\text { Nonlinearities in the U.S. } \\
\text { corn-ethanol-oil-gasoline } \\
\text { price system }\end{array}$ & $\begin{array}{l}\text { Agricultural } \\
\text { Economics }\end{array}$ & 19 & 1 & None & $\begin{array}{l}\text { Smooth } \\
\text { Transition } \\
\text { Vector Error } \\
\text { Correction } \\
\text { Model } \\
\end{array}$ & $\begin{array}{l}\text { Results indicate the existence of long-run } \\
\text { relationships among the prices studied. } \\
\text { There were also strong links identified } \\
\text { between energy and food prices. }\end{array}$ \\
\hline
\end{tabular}




\begin{tabular}{|c|c|c|c|c|c|c|c|c|}
\hline 55 & $\begin{array}{l}\text { Alam et al. } \\
(2012), \\
\text { Bangladesh }\end{array}$ & $\begin{array}{l}\text { The dynamic } \\
\text { relationships between } \\
\text { world and domestic } \\
\text { prices of rice under the } \\
\text { regime of agricultural } \\
\text { trade liberalization in } \\
\text { Bangladesh }\end{array}$ & $\begin{array}{l}\text { Journal of the } \\
\text { Asia Pacific } \\
\text { Economy }\end{array}$ & 10 & 1 & None & $\begin{array}{l}\text { Johansen } \\
\text { multivariate } \\
\text { co-integration, } \\
\text { VECM }\end{array}$ & $\begin{array}{l}\text { This paper highlights the dependence of } \\
\text { Bangladeshi rice market on the world rice } \\
\text { market and underline the need for adequate } \\
\text { policies which specifically address the } \\
\text { issue of food security when world prices } \\
\text { are very high. }\end{array}$ \\
\hline 56 & $\begin{array}{l}\text { Asche et al. } \\
(2012), \\
\text { Tanzania }\end{array}$ & $\begin{array}{l}\text { Testing the central } \\
\text { market hypothesis: a } \\
\text { multivariate analysis of } \\
\text { Tanzanian sorghum } \\
\text { markets }\end{array}$ & $\begin{array}{l}\text { Agricultural } \\
\text { Economics }\end{array}$ & 10 & 1 & None & $\begin{array}{l}\text { Multivariate } \\
\text { co-integration, } \\
\text { Johansen co- } \\
\text { integration }\end{array}$ & $\begin{array}{l}\text { This article shows that the central market } \\
\text { hypothesis can be tested in a Johansen co- } \\
\text { integration test provided that prices are } \\
\text { non-stationary. The results indicate that } \\
\text { Tanzanian sorghum market can be grouped } \\
\text { into two market regions, with prices being } \\
\text { determined in a central market in each } \\
\text { region. }\end{array}$ \\
\hline 57 & $\begin{array}{l}\text { Sekhar (2012), } \\
\text { India }\end{array}$ & $\begin{array}{l}\text { Agricultural market } \\
\text { integration in India: an } \\
\text { analysis of select } \\
\text { commodities }\end{array}$ & Food Policy & 21 & 1 & Trade policies & $\begin{array}{l}\text { Gonzalo- } \\
\text { Granger } \\
\text { model }\end{array}$ & $\begin{array}{l}\text { According to this paper, commodity } \\
\text { markets that do not face inter-state or inter- } \\
\text { regional movement restrictions, like gram } \\
\text { and edible oils, appear well-integrated. On } \\
\text { the contrary, rice market, subject to the } \\
\text { maximum inter-state movement } \\
\text { restrictions, does not show integration at } \\
\text { the national level. The broad implication of } \\
\text { the study is that markets can play a more } \\
\text { effective role if supplemented with more } \\
\text { open policy initiatives. }\end{array}$ \\
\hline 58 & $\begin{array}{l}\text { Zant (2012), } \\
\text { Malawi }\end{array}$ & $\begin{array}{l}\text { How is the liberalization } \\
\text { of food markets } \\
\text { progressing? Market } \\
\text { integration and } \\
\text { transaction costs in } \\
\text { subsistence economies }\end{array}$ & $\begin{array}{l}\text { World Bank } \\
\text { Economic } \\
\text { Review }\end{array}$ & 10 & 1 & $\begin{array}{l}\text { Market } \\
\text { liberalisation, } \\
\text { transaction } \\
\text { costs }\end{array}$ & PBM & $\begin{array}{l}\text { The study found out that probabilities of } \\
\text { market regimes, computed on the basis of } \\
\text { predicted transaction costs, fluctuate } \\
\text { significantly and do not support fixed } \\
\text { regime probabilities over time. The } \\
\text { probability of market integration with trade } \\
\text { decreases consistently during food } \\
\text { shortages, increasing either the probability } \\
\text { of no trade or loss-making trade or the } \\
\text { probability of profitable but unexploited } \\
\text { trade opportunities. This paper proposed a } \\
\text { modification to Baulch's PBM. }\end{array}$ \\
\hline
\end{tabular}




\begin{tabular}{|c|c|c|c|c|c|c|c|c|}
\hline 59 & $\begin{array}{l}\text { Götz et al. } \\
\text { (2013), Russia } \\
\text { and Ukraine }\end{array}$ & $\begin{array}{l}\text { Wheat export restrictions } \\
\text { and domestic market } \\
\text { effects in Russia and } \\
\text { Ukraine during the food } \\
\text { crisis }\end{array}$ & Food Policy & 4 & 4 & $\begin{array}{l}\text { Export } \\
\text { restrictions }\end{array}$ & $\begin{array}{l}\text { Markov- } \\
\text { switching } \\
\text { VECM }\end{array}$ & $\begin{array}{l}\text { Results show that export restrictions } \\
\text { temporarily reduced the degree of } \\
\text { integration of Russian and Ukrainian } \\
\text { domestic markets in world wheat markets, } \\
\text { which pushed the growers' prices below } \\
\text { their long-run equilibrium level. Domestic } \\
\text { markets were also disconnected from their } \\
\text { equilibrium and market instability } \\
\text { increased. }\end{array}$ \\
\hline 60 & $\begin{array}{l}\text { Weldesenbet } \\
(2013), \\
\text { Slovakia }\end{array}$ & $\begin{array}{l}\text { Asymmetric price } \\
\text { transmission in the } \\
\text { Slovak liquid milk } \\
\text { market }\end{array}$ & $\begin{array}{l}\text { Agricultural } \\
\text { Economics }\end{array}$ & 18 & 1 & None & $\begin{array}{l}\text { Granger } \\
\text { causality, } \\
\text { Johansen co- } \\
\text { integration, } \\
\text { ECM }\end{array}$ & $\begin{array}{l}\text { Results reveal that wholesale and producer } \\
\text { prices as well as the retail and producer } \\
\text { prices were co-integrated, but there was no } \\
\text { evidence of co-integration between the } \\
\text { wholesale and retail prices. Price } \\
\text { transmission in the Slovakian liquid milk } \\
\text { market was found to be asymmetric both in } \\
\text { the short- and long-run. }\end{array}$ \\
\hline 61 & $\begin{array}{l}\text { Baquedano } \\
\text { and Liefert } \\
(2014), \text { USA }\end{array}$ & $\begin{array}{l}\text { Market integration and } \\
\text { price transmission in } \\
\text { consumer markets of } \\
\text { developing countries }\end{array}$ & Food Policy & 5 & 29 & None & $\begin{array}{l}\text { Single } \\
\text { Equation Error } \\
\text { Correction } \\
\text { Model } \\
\text { (SEECM), co- } \\
\text { integration }\end{array}$ & $\begin{array}{l}\text { Results show that developing countries' } \\
\text { consumer markets were co-integrated with } \\
\text { world markets. Transmission of changes in } \\
\text { both world market prices and real } \\
\text { exchange rates to domestic consumer } \\
\text { prices was not high. Movement of } \\
\text { domestic consumer prices to new } \\
\text { equilibrium with world market prices after } \\
\text { a shock to the latter was relatively slow. }\end{array}$ \\
\hline 62 & $\begin{array}{l}\text { Bor et al. } \\
\text { (2014), } \\
\text { Turkey }\end{array}$ & $\begin{array}{l}\text { Asymmetry in farm- } \\
\text { retail price transmission } \\
\text { in the Turkish fluid milk } \\
\text { market }\end{array}$ & $\begin{array}{l}\text { New medit: } \\
\text { Mediterranean } \\
\text { journal of } \\
\text { economics, } \\
\text { agriculture \& } \\
\text { environment }\end{array}$ & 10 & 1 & Market power & $\begin{array}{l}\text { Co- } \\
\text { integration, } \\
\text { ECM }\end{array}$ & $\begin{array}{l}\text { Results suggest a positive price asymmetry } \\
\text { in the farm-retail price transmission in the } \\
\text { Turkish milk market. Co-integration results } \\
\text { imply a significant market power in the } \\
\text { Turkish fluid milk market. These results } \\
\text { support the view that retailers can exercise } \\
\text { significant market power. }\end{array}$ \\
\hline 63 & $\begin{array}{l}\text { García- } \\
\text { Enríquez et al. } \\
(2014), \text { Spain }\end{array}$ & $\begin{array}{l}\text { Spatial integration in the } \\
\text { Spanish mackerel market }\end{array}$ & $\begin{array}{l}\text { Journal of } \\
\text { Agricultural } \\
\text { Economics }\end{array}$ & 12 & 1 & None & Co-integration & $\begin{array}{l}\text { Results indicate that the Spanish mackerel } \\
\text { market was not integrated. There were no } \\
\text { links, at least in the long term, between any } \\
\text { of Spain's five regional markets. The } \\
\text { results have significant implications in } \\
\text { policy terms, as local, regional and }\end{array}$ \\
\hline
\end{tabular}




\begin{tabular}{|c|c|c|c|c|c|c|c|c|}
\hline & & & & & & & & $\begin{array}{l}\text { European authorities must take into } \\
\text { account the need to apply distinct local } \\
\text { policies. }\end{array}$ \\
\hline 64 & $\begin{array}{l}\text { Ianchovichina } \\
\text { et al. (2014), } \\
\text { Saudi Arabia }\end{array}$ & $\begin{array}{l}\text { How vulnerable are Arab } \\
\text { countries to global food } \\
\text { price shocks? }\end{array}$ & $\begin{array}{l}\text { Journal of } \\
\text { Development } \\
\text { Studies }\end{array}$ & 12 & 18 & None & $\begin{array}{l}\text { Co- } \\
\text { integration, } \\
\text { VAR }\end{array}$ & $\begin{array}{l}\text { Findings from this study suggest that } \\
\text { international food price shocks are } \\
\text { transmitted to various degrees into } \\
\text { domestic markets. The magnitude of the } \\
\text { estimates appears to be in line with } \\
\text { empirical evidence for other countries, } \\
\text { even though caution is required when } \\
\text { interpreting the coefficients' magnitudes } \\
\text { given differences in the composition of } \\
\text { national and world food baskets. }\end{array}$ \\
\hline 65 & $\begin{array}{l}\text { Minten et al. } \\
\text { (2014), } \\
\text { Ethiopia }\end{array}$ & $\begin{array}{l}\text { Structural transformation } \\
\text { of cereal markets in } \\
\text { Ethiopia }\end{array}$ & $\begin{array}{l}\text { Journal of } \\
\text { Development } \\
\text { Studies }\end{array}$ & 11 & 1 & None & TAR & $\begin{array}{l}\text { Results show that cereal markets in } \\
\text { Ethiopia, over the last decade, have } \\
\text { undergone important local changes such as } \\
\text { strong economic growth, urbanisation, } \\
\text { improved road and communication } \\
\text { infrastructure, and higher adoption of } \\
\text { modern inputs in agriculture. These } \\
\text { changes are associated with better spatial } \\
\text { price integration as well as with significan } \\
\text { declines in real price differences between } \\
\text { supplying and receiving markets and in } \\
\text { cereal milling and retail margins. In short, } \\
\text { important improvements have occurred in } \\
\text { Ethiopia's cereal marketing system. }\end{array}$ \\
\hline
\end{tabular}




\subsection{Results and discussion}

A comprehensive bibliography of the literature on food market integration is presented in Table 1, classified on the basis of the variables mentioned in Figure 1. Each of the variable and the results obtained from the review is discussed in this section.

\subsection{Econometric tools/methodology used in data analysis}

The frequency of various econometric tools adopted for data analysis in the papers reviewed is presented in Table 2. The majority of the studies used co-integration analysis, followed by parity bounds model, threshold autoregression, vector autoregression, Ravallion, and error correction model in testing food market integration. Others used autoregressive conditional heteroskedastic regression, threshold co-integration, and Johansen co-integration and vector error correction models. Less popular econometric tools are also shown in Table 2; they include coefficient of variation, multivariate generalized autoregressive conditional heteroscedasticity, multivariate co-integration, Granger-causality, Markov-switching vector error- correction model, seemingly unrelated regression error and many others.

Table 2: Summary of results on literature review of food market integration studies

\begin{tabular}{lr} 
Variable & No. of studies \\
\hline Econometric tools/methodology used in data analysis (multiple response) & \\
Model & 23 \\
Co-integration & 7 \\
Parity bounds model (PBM) & 4 \\
Threshold Auto-regression (TAR) & 4 \\
Vector auto- regression (VAR) & 4 \\
Ravallion & 4 \\
Error correction model (ECM) & 3 \\
Autoregressive conditional heteroskedastic regression (Gluschenko and & 3 \\
Karchevskaya) & 3 \\
Threshold co-integration & 3 \\
Johansen co-integration & 2 \\
Vector Error correction model (VECM) & 2 \\
Coefficient of variation & 2 \\
Multivariate generalized autoregressive conditional heteroskedasticity & 2 \\
(MGARCH) & 2 \\
Multivariate co-integration & 2 \\
Granger-causality & 2 \\
Markov-switching vector error- correction model & 14 \\
Extended Parity Bounds Model & 86 \\
Seemingly unrelated regression Error (Goletti and Babu) & 2 \\
Other econometric tools* &
\end{tabular}

Other econometric tools include: Threshold regression, Switching regime regression, momentum threshold auto-regressive models, autoregressive distributed lag model, correlation, Johansen multivariate co-integration, Timmer, generalized error correction, single equation error correction model, smooth transition vector error correction model, Kwiatkowski-Phillips-Schmidt-Shin, seemingly unrelated regression-augmented Dickey-Fuller, Gonzalo-Granger model, and error correction representation.

\section{Year wise classification of studies \\ Year}

1990-1994 7

1995-1999 15

2000-2004 11

2005-2009 14 
Country wise distribution of studies

Country

USA

China

Ethiopia

5

Ghana

4

India

Indonesia

Russia

3

UK

Brazil

Burkina Faso

Malawi

Tanzania

Vietnam

DRC (Zaire)

Benin

Germany

Other countries*

Total

Other countries include: Bangladesh, Canada, Colombia, Italy, Madagascar, Mali, Mozambique, Norway, Philippines, Slovak, Slovenia, Spain, Turkey, Uganda, Ukraine, Nepal, Niger and Saudi Arabia

\begin{tabular}{lr}
\hline Number of years taken as a sample data set & \\
Number of sample years & 22 \\
$1-5$ & 17 \\
$6-10$ & 14 \\
$11-15$ & 6 \\
$16-20$ & 3 \\
$21-25$ & 1 \\
$26-30$ & 2 \\
More than 51 & 65 \\
Total & \\
\hline Number of countries considered for study & \\
Number of sample countries & 60 \\
$1-10$ & 4 \\
$11-20$ & 1 \\
$21-30$ & 65 \\
Total & \\
\hline Sources from where literature was collected & 12 \\
Journal name & 10 \\
Agricultural Economics & 6 \\
American Journal of Agricultural Economics & 6 \\
Food Policy & 6 \\
Journal of African Economies & 6 \\
Journal of Development Studies & 5 \\
European Review of Agricultural Economics & 3 \\
Applied Economics & 2 \\
Journal of Agricultural Economics & 2 \\
Other journals* & 13 \\
Total & 65 \\
Other journals include: World Bank Economic Review, Journal of Economic History, Oxford & \\
\hline
\end{tabular}


Bulletin of Economics and Statistics, Journal of Agricultural and Resource Economics, Review of Economics and Statistics, Empirical Economics, Journal of the Asia Pacific Economy, Agricultural and food science, Contemporary Economic Policy, Economics of Transition, Explorations in Economic History, Journal of Regional Science and New medit

\subsection{Year and country wise distribution of studies}

Although the trend in food market integration has been fluctuating, with least researches recorded in early 1990s, there has been a general increase in research in this field since mid2000s. It can be observed from Table 2 that the majority of the studies were conducted in the period between 2010 and 2014. More than 50 percent of the reviewed work was done in the last 10 years of the study period, i.e. from 2005 to 2014 .

Country wise distribution of the studies is also shown in Table 2. Out of the 65 papers, 6 were from USA, 5 from China, Ethiopia and Ghana had 4 papers each, India, Indonesia, Russia and UK each had 3 papers. Countries that had two studies each are Brazil, Burkina Faso, Malawi, Tanzania, Vietnam, Democratic Republic of Congo (DRC), Benin and Germany. The rest of the countries under the category of "others" each had only one study.

\subsection{Number of years taken as sample}

Table 2 further describes the number of years considered as sample for each study. Most studies had a sample size of less than five years. Out of the 65 studies, 53 had datasets with time frame between one and 15 years and six had datasets falling between 16 to 20 years. Three studies had datasets falling between 21 to 25 years. Only one study had a dataset of 26 to 30 years. The remaining two studies had datasets with more than 51 years each.

\subsection{Number of countries considered for study forming sample data}

The number of countries considered for each study is shown in Table 2. These results reveal that all the papers sampled covered less than 30 countries. Out of the 65 papers, 60 used less than ten countries in their analysis. Four studies sampled 11 to 20 countries and only one study covered a sample of between 21 and 30 countries. The majority of the studies sampled less than ten countries possibly because of scarcity of data on food markets in some countries.

\subsection{Sources of data collection}

The papers reviewed were collected from different A1 journals as summarized in Table 2. Results show that most of them (12 out of 65) were collected from Agricultural economics journal, followed by American Journal of Agricultural Economics, Food Policy, Journal of African Economies, Journal of Development Studies, European Review of Agricultural Economics, Journal of Development Economics, Applied Economics and Journal of Agricultural Economics. The remaining 13 papers were collected from other journals as shown in Table 2.

\subsection{Determinants of market integration}

Several factors can increase the degree of integration of food markets, these include: physical infrastructure, information, institutions, competition, market power, trade, social capital and policies, which facilitate market exchanges (Table 3). The transaction costs associated with these factors are the key determinants of market integration. These factors or determinants of market integration operate by lowering transaction costs that affect the flow of goods and information between markets. In this section, we present an analysis of the determinants of market integration, as per the extensive literature review. We further present some questions related to food market integration that can be addressed by future research. 
Table 3: Determinants of market integration

\begin{tabular}{lrr}
\hline Variable & No. of studies & Percentage \\
\hline Studies that addressed determinants of market integration & & \\
Yes & 26 & 40 \\
No & 39 & 60 \\
Total & 65 & 100 \\
\hline Determinants of market integration identified in the & & \\
studies (multiple response) & & \\
Determinant & & \\
Roads (distance, quality, rehabilitation, transport facilities, fuel & 8 & 17.4 \\
prices & 8 & 17.4 \\
Trade (policies, volumes, restrictions, quality, seasonality) & 8 & 17.4 \\
Transaction costs & 7 & 15.2 \\
Market liberalisation & 6 & 13 \\
Infrastructure (physical, market and communication & 2 & 4.3 \\
Government intervention & 2 & 4.3 \\
Information services & 1 & 2.2 \\
Inflation & 1 & 2.2 \\
Inventory management & 1 & 2.2 \\
Market institutions & 1 & 2.2 \\
Means of communication & 1 & 2.2 \\
Urbanisation & 46 & 100 \\
Total & & \\
\hline
\end{tabular}

\subsubsection{Physical infrastructure}

A market is a complex institution and its performance depends on numerous factors. One of the most important factors is the quality of roads or physical infrastructure. Poor roads lead to an increase in transportation costs in the following ways: higher fuel consumption, higher maintenance costs, faster depreciation of vehicles, tyre replacement costs, and loss of time due to lower speeds (Taravaninthorn and Raballand, 2009). Some studies have quantified the effect of road quality on transportation costs and market integration. One of the studies conducted in Rwanda showed that a road improvement project reduced the price differences between two markets and increased the correlation of their prices over time (Loveridge, 1991). Another study by Minten and Kyle (1999) found that transportation cost was twice as high on poor roads as on paved roads in Zaire (now Democratic Republic of Congo). The higher cost of transportation on poor roads resulted in lower prices received by farmers on selling their crops. Generally, most studies have been on how the quality and distance of physical infrastructure affects the degree of market integration.

\subsubsection{Market institutions and information}

Institutions and information are very important determinants of transaction costs and market integration (Rashid and Minot, 2010, Muto and Yamano, 2009, De Bruyn et al., 2001, Worako et al., 2008). In the absence or incomplete or missing institutions, personalised market transactions are very common. But if market institutions are functional, then personalised transactions are rare (Aker, 2009, Goyal, 2010, Geertz, 1996). Market information is essential for location of buyers and sellers. Sometime back, in rural areas of developing countries, information flow was by word of mouth and through informal channels. Currently, however, the importance of radios, televisions, newspapers and telephones is increasing. Because of high illiteracy levels, a radio is the most important mechanism for farming communities to obtain information on agricultural markets. There is also a rapid expansion in the use of mobile phones among farming communities and traders (Jensen, 2007, Jensen, 2010, Bayes, 2001, Abraham, 2006, Donner, 2008, Muto and Yamano, 2009). With 
the popularity of mobile phones in agriculture, there is no doubt that information on prices is exchanged faster than it used to be sometime back. There are studies which have been conducted on mobile phone usage in food markets (Abraham, 2006, Muto and Yamano, 2009). However, more research is still needed on how mobile phone popularity has affected the degree of integration of food markets. From our review, we did not get clear answers to this research question.

\subsubsection{Competition and market power}

Whereas some studies suggest existence of market power in food markets, others suggest otherwise. A study by Abdulai (2000) found asymmetry in price transmission in Ghana, suggesting some market power. Bor et al. (2014) also found asymmetry in farm-retail price transmission in Turkish milk markets, implying significant market power. Osborne (2005) found evidence of imperfect competition among wholesalers in smaller markets which were isolated from the main cities in Ethiopia. The impact of imperfect competition, however, was modest, reducing producer prices by 3 percent. On the other hand, Goletti and Babu (1994) did not find any asymmetry in maize markets in Malawi. From this review, it is not obvious what the effect of a lack of competition and presence of market power should be on the degree of integration. A marketing structure that is more concentrated is likely to achieve certain economies of scale in trade and information, which can lower costs. On the contrary, markets that are less competitive could restrict flows in order to raise prices and profits (Goodwin and Schroeder, 1991). More empirical research is required to clarify these issues.

\subsubsection{Trade}

A larger volume of inter-regional trade should lead to a higher degree of integration since it contributes to reducing transaction costs (González-Rivera and Helfand, 2001). Some studies demonstrate that per unit transportation costs are an inverse function of volume (Jensen, 2010, Gabre-Madhin, 2001). There are quantity discounts due to factors such as use of larger trucks, lower per unit costs of loading and unloading larger quantities and reduced logistical costs. There are also studies which show that large volumes of trade do not necessary generate high degree of integration (Klaes, 2000, Somda et al., 2005). Trade, as a determinant of market integration, still needs to be studied further. There is need to study how factors like demand and supply, which are related to trade, can affect the degree of integration (Gonzalez-Rivera and Helfand, 2001, Key et al., 2000). Also, more research into the combined effect of all the three, i.e. demand, supply and trade, on market integration is needed.

\subsubsection{Social capital}

Social capital relates to trust and networks that allow people to cooperate (González-Rivera and Helfand, 2001). It is a factor that can lower transaction costs of information flow, monitoring and enforcement. Social capital in form of networks can increase information flow and productivity. Also, social capital in form of trust can lower transaction costs and facilitate trade flows. Social capital, therefore, is very relevant to the study of market integration. More empirical research on how social capital influences price transmission and market integration needs to be done. To date, very little research has been done on how this determinant affects market integration.

\subsubsection{Public policies}

Policies by governments directly or indirectly affect food markets. Examples of public policies include public/government intervention in food markets and export restrictions/bans. Below we discuss the relationship between these policies and market integration. 


\section{Public/government intervention}

Governments in many countries, especially in Africa, continue to intervene heavily in food markets. These interventions are done by state enterprises. Countries with high level of state interventions in food markets include Ethiopia, Kenya, Malawi, Zambia, China and Indonesia (Rashid and Minot, 2010). Other countries with some level of state intervention include Tanzania, Mozambique and Uganda. Typically, intervention by governments is aimed at maintaining grain stocks for emergency use. It is also an attempt to stabilise grain prices and provide grain to remote deficit areas. Depending on the motive, government intervention may either improve or hinder the integration of food markets. For the case of China, this intervention has been a major hindrance to market integration (Zhou et al., 2000, Park et al., 2002). On the other hand, Indonesian government's intervention in terms of rice procurement has improved the integration of rice markets in the country (Alexander and Wyeth, 1994, Ismet et al., 1998). Government intervention has both positive and negative effects on market integration. The relationship between government intervention and price transmission still needs further research.

\section{Export restrictions/bans}

In the presence of export bans/restrictions, food markets do not operate freely between countries. Even market information does not move freely, which affects market integration. There are countries, like Tanzania, which have followed a practice of banning food exports following poor harvest to ensure that local supplies go to deficit areas within the country (Rashid and Minot, 2010). Kenya maintains high import duties on maize from outside the East African Community, and has imposed temporary restrictions on maize imports from East African Community countries to protect its farmers (Rashid and Minot, 2010). Generally, export bans/restrictions are not good for food markets. They reduce the degree of market integration. This needs to be proved further by research. More issues that need research include effect of export restrictions on price volatility and price transmission in food markets.

From our analysis, we appreciate the work that has so far been done on determinants of market integration. However, we have also found out that there is still a lot that needs to be done in order to address the issues that have been raised.

\subsection{Conclusions and future research}

The objectives of this review were to: analyse the state of the art research on food market integration; classify it; and provide a perspective for future research. The contribution of research work in food market integration during the period under study, i.e. 1990 to 2014, has been increasing continuously. This is especially evident from 2009 to 2014. Much of the work has concentrated on countries like USA, Ethiopia, China, Ghana, India, Russia and Malawi. However, there are many countries which have not caught the attention of researchers in this field. Future research should therefore include countries which have not been covered. Sample data and sample countries considered for future research should be altered to notice any variation in research results.

We have also noted the growth in research in food market integration. However, little has been done regarding application of this research. The majority of the research has concentrated relatively more on identifying the degree of linkages among markets.

We also appreciate the work that has been done on determinants of market integration and, hence, identified the following factors as very important: physical infrastructure, market institutions, information, competition, market power, trade, social capital, public/government 
intervention and export restrictions/bans. Notwithstanding the work that has been done on market integration, there is still much that needs to be done. Future research on food market integration should address the following questions. How does the quality of physical infrastructure/roads affect the speed of adjustment of markets in case of a shock? How has the popularity of mobile phone use among the farming communities affected the degree of food market integration? How does trust and networking among farmers and traders influence price transmission and market integration? What is the effect of export restrictions on price volatility and price transmission in food markets?

\section{References}

ABDULAI, A. 2000. Spatial price transmission and asymmetry in the Ghanaian maize market. Journal of Development Economics, 63, 327-349.

ABRAHAM, R. Mobile phones and economic development: Evidence from the fishing industry in India. Information and Communication Technologies and Development, 2006. ICTD'06. International Conference on, 2006. IEEE, 48-56.

ABUNYUWAH, I. 2007. Market Integration Analysis and Time-series Econometrics: Conceptual Insights from Markov-switching Models. Doctoral Dissertation: Faculty of Agricultural Sciences Georg-August-University of Göttingen, Germany.

AKER, J. 2009. Information from markets near and far: Information technology, search costs and grain markets. Mimeo, Tufts University.

ALAM, M. J., BUYSSE, J., MCKENZIE, A. M., BEGUM, I. A., WAILES, E. J. \& VAN HUYLENBROECK, G. 2012. The dynamic relationships between world and domestic prices of rice under the regime of agricultural trade liberalization in Bangladesh. Journal of the Asia Pacific Economy, 17, 113-126.

ALDERMAN, H. 1993. Intercommodity price transmittal: analysis of food markets in Ghana. Oxford Bulletin of Economics and Statistics, 55, 43-64.

ALEXANDER, C. \& WYETH, J. 1994. Cointegration and market integration: An application to the Indonesian rice market. The Journal of Development Studies, 30, 303-334.

ARAUJO, C. 2005. Devaluation and Cattle Market Integration in Burkina Faso. Journal of African Economies, 14, 359-384.

ASCHE, F., GJØLBERG, O. \& GUTTORMSEN, A. G. 2012. Testing the central market hypothesis: a multivariate analysis of Tanzanian sorghum markets. Agricultural Economics, 43, 115-123.

ASCHE, F., JAFFRY, S. \& HARTMANN, J. 2007. Price transmission and market integration: vertical and horizontal price linkages for salmon. Applied Economics, 39, $2535-2545$.

AWOKUSE, T. O. 2007. Market reforms, spatial price dynamics, and China's rice market integration: a causal analysis with directed acyclic graphs. Journal of Agricultural and Resource Economics, 58-76.

BADIANE, O. \& SHIVELY, G. E. 1998. Spatial integration, transport costs, and the response of local prices to policy changes in Ghana. Journal of Development Economics, 56, 411-431.

BAQUEDANO, F. G., LIEFERT, W. \& SHAPOURI, S. 2011. World market integration for export and food crops in developing countries: a case study for Mali and Nicaragua. Agricultural Economics, 42, 619-630.

BAQUEDANO, F. G. \& LIEFERT, W. M. 2014. Market integration and price transmission in consumer markets of developing countries. Food Policy, 44, 103-114.

BARRETT, C. B. \& LI, J. R. 2002. Distinguishing between equilibrium and integration in spatial price analysis. American Journal of Agricultural Economics, 84, 292-307. 
BAULCH, B. 1997a. Testing for food market integration revisited. The Journal of Development Studies, 33, 512-534.

BAULCH, B. 1997b. Transfer costs, spatial arbitrage, and testing for food market integration. American Journal of Agricultural Economics, 79, 477-487.

BAULCH, B., HANSEN, H., TRUNG, L. D. \& TAM, T. N. M. 2008. The Spatial Integration of Paddy Markets in Vietnam. Journal of Agricultural Economics, 59, 271-295.

BAYES, A. 2001. Infrastructure and rural development: insights from a Grameen Bank village phone initiative in Bangladesh $\star$. Agricultural Economics, 25, 261-272.

BOJNEC, S. \& PETER, G. 2005. Vertical market integration and competition: the meat sector in Slovenia. Agricultural and Food Science, 14, 236-249.

BOR, O., SMIHAN, M. \& BAYANER, A. 2014. Asymmetry in farm-retail price transmission in the Turkish fluid milk market. New medit: Mediterranean journal of economics, agriculture and environment= Revue méditerranéenne d'economie, agriculture et environment, 13, 2-8.

BRUMMER, B., VON CRAMON-TAUBADEL, S. \& ZORYA, S. 2009. The impact of market and policy instability on price transmission between wheat and flour in Ukraine. European Review of Agricultural Economics, 36, 203-230.

CIRERA, X. \& ARNDT, C. 2008. Measuring the impact of road rehabilitation on spatial market efficiency in maize markets in Mozambique. Agricultural Economics, 39, 1728.

COLEMAN, A. 2009. Storage, slow transport, and the law of one price: Theory with evidence from nineteenth-century US corn markets. The Review of Economics and Statistics, 91, 332-350.

CUDJOE, G., BREISINGER, C. \& DIAO, X. 2010. Local impacts of a global crisis: Food price transmission, consumer welfare and poverty in Ghana. Food Policy, 35, 294302.

DAHLGRAN, R. A. \& BLANK, S. C. 1992. Evaluating the integration of contiguous discontinuous markets. American Journal of Agricultural Economics, 74, 469-479.

DE BRUYN, P., DE BRUYN, J., VINK, N. \& KIRSTEN, J. F. 2001. How transaction costs influence cattle marketing decisions in the northern communal areas of Namibia. Agrekon, 40, 405-425.

DERCON, S. 1995. On market integration and liberalisation: method and application to Ethiopia. The Journal of Development Studies, 32, 112-143.

DONNER, J. 2008. Research approaches to mobile use in the developing world: A review of the literature. The information society, 24, 140-159.

FAFCHAMPS, M. \& GAVIAN, S. 1996. The spatial integration of livestock markets in Niger. Journal of African Economies, 5, 366-405.

FAMINOW, M. D. \& BENSON, B. L. 1990. Integration of spatial markets. American Journal of Agricultural Economics, 72, 49-62.

GABRE-MADHIN, E. Z. 2001. Market institutions, transaction costs, and social capital in the Ethiopian grain market, Intl Food Policy Res Inst.

GARCÍA-ENRÍQUEZ, J., HUALDE, J., ARTECHE, J. \& MURILLAS-MAZA, A. 2014. Spatial Integration in the Spanish Mackerel Market. Journal of Agricultural Economics, 65, 234-256.

GARDNER, B. L. \& BROOKS, K. M. 1994. Food prices and market integration in Russia: 1992-93. American Journal of Agricultural Economics, 76, 641-646.

GE, Y., WANG, H. H. \& AHN, S. K. 2010. Cotton market integration and the impact of China's new exchange rate regime. Agricultural Economics, 41, 443-451.

GEERTZ, C. 1996. The bazaar economy: information and search in peasant marketing. INTERNATIONAL LIBRARY OF CRITICAL WRITINGS IN ECONOMICS, 70, 78-82. 
GETNET, K., VERBEKE, W. \& VIAENE, J. 2005. Modeling spatial price transmission in the grain markets of Ethiopia with an application of ARDL approach to white teff. Agricultural Economics, 33, 491-502.

GHOSHRAY, A. 2011. Underlying Trends and International Price Transmission of Agricultural Commodities. Asian Development Bank Economics Working Paper Series.

GHOSHRAY, A. \& GHOSH, M. 2011. How integrated is the Indian wheat market? Journal of Development Studies, 47, 1574-1594.

GLUSCHENKO, K. \& KARCHEVSKAYA, D. 2010. Assessing a feasible degree of product market integration: a pilot analysis. Journal of Economic Studies, 37, 419-437.

GOLETTI, F., AHMED, R. \& FARID, N. 1995. Structural determinants of market integration: The case of rice markets in Bangladesh. The Developing Economies, 33, 196-198.

GOLETTI, F. \& BABU, S. 1994. Market liberalization and integration of maize markets in Malawi. Agricultural Economics, 11, 311-324.

GONZALEZ-RIVERA, G. \& HELFAND, S. M. 2001. The extent, pattern, and degree of market integration: A multivariate approach for the Brazilian rice market. American Journal of Agricultural Economics, 83, 576-592.

GONZÁLEZ-RIVERA, G. \& HELFAND, S. M. 2001. Economic development and the determinants of spatial integration in agricultural markets, Department of Economics, University of California, Riverside.

GOODWIN, B. K. \& PIGGOTT, N. E. 2001. Spatial market integration in the presence of threshold effects. American Journal of Agricultural Economics, 83, 302-317.

GOODWIN, B. K. \& SCHROEDER, T. C. 1991. Cointegration tests and spatial price linkages in regional cattle markets. American Journal of Agricultural Economics, 73, 452-464.

GÖTZ, L., GLAUBEN, T. \& BRÜMMER, B. 2013. Wheat export restrictions and domestic market effects in Russia and Ukraine during the food crisis. Food Policy, 38, 214-226.

GOYAL, A. 2010. Information, direct access to farmers, and rural market performance in central India. World Bank Policy Research Working Paper Series, Vol.

IANCHOVICHINA, E. I., LOENING, J. L. \& WOOD, C. A. 2014. How Vulnerable are Arab Countries to Global Food Price Shocks? The Journal of Development Studies, 50, $1302-1319$.

IREGUI, A. M. \& OTERO, J. 2010. Testing the law of one price in food markets: evidence for Colombia using disaggregated data. Empirical Economics, 40, 269-284.

ISMET, M., BARKLEY, A. P. \& LLEWELYN, R. V. 1998. Government intervention and market integration in Indonesian rice markets. Agricultural Economics, 19, 283-295.

JENSEN, R. 2007. The digital provide: Information (technology), market performance, and welfare in the South Indian fisheries sector. The quarterly journal of economics, 879924.

JENSEN, R. T. 2010. Information, efficiency, and welfare in agricultural markets. Agricultural Economics, 41, 203-216.

KEY, N., SADOULET, E. \& DE JANVRY, A. 2000. Transactions costs and agricultural household supply response. American journal of agricultural economics, 82, 245-259.

KLAES, M. 2000. The history of the concept of transaction costs: Neglected aspects. Journal of the History of Economic Thought, 22, 191-216.

KUIPER, W. E., LUTZ, C. \& VAN TILBURG, A. 1999. Testing for the Law of One Price and Identifying Price-Leading Markets: An Application to Corn Markets in Benin. Journal of Regional Science, 39, 713-738. 
LI, L. M. 2000. Integration and Disintegration in North China's Grain Markets, 1738-1911. The Journal of Economic History, 60, 665-699.

LLOYD, T., MCCORRISTON, S., MORGAN, C. \& RAYNER, A. J. 2001. The impact of food scares on price adjustment in the UK beef market. Agricultural Economics, 25, 347-357.

LOVERIDGE, S. 1991. Marketing in Rwanda imports and infrastructure. Food Policy, 16, 95-104.

LOY, J.-P. \& WEAVER, R. D. 1998. Inflation and relative price volatility in Russian food markets. European Review of Agricultural Economics, 25, 373-394.

LUTZ, C. \& BASSOLET, B. 1999. Information Service and Integration of Cereal Markets in Burkina Faso. Journal of African Economies, 8, 31-51.

LUTZ, C., KUIPER, W. E. \& VAN TILBURG, A. 2006a. Maize Market Liberalisation in Benin: A Case of Hysteresis. Journal of African Economies, 16, 102-133.

LUTZ, C., PRAAGMAN, C. \& THANH DUC HAI, L. 2006b. Rice market integration in the Mekong River Delta1. Economics of Transition, 14, 517-546.

MARKS, D. 2010. Unity or diversity? On the integration and efficiency of rice markets in Indonesia, c. 1920-2006. Explorations in Economic History, 47, 310-324.

MEYER, J. 2004. Measuring market integration in the presence of transaction costs-a threshold vector error correction approach. Agricultural Economics, 31, 327-334.

MINOT, N. 2010. Transmission of world food price changes to markets in Sub-Saharan Africa, International Food Policy Research Institute Washington.

MINTEN, B. \& KYLE, S. 1999. The effect of distance and road quality on food collection, marketing margins, and traders' wages: evidence from the former Zaire. Journal of Development Economics, 60, 467-495.

MINTEN, B. \& KYLE, S. 2000. Retail margins, price transmission and price asymmetry in urban food markets: The case of Kinshasa (Zaire). Journal of African Economies, 9, 123.

MINTEN, B., STIFEL, D. \& TAMRU, S. 2014. Structural Transformation of Cereal Markets in Ethiopia. The Journal of Development Studies, 50, 611-629.

MOSER, C., BARRETT, C. \& MINTEN, B. 2009. Spatial integration at multiple scales: rice markets in Madagascar. Agricultural Economics, 40, 281-294.

MUTO, M. \& YAMANO, T. 2009. The impact of mobile phone coverage expansion on market participation: Panel data evidence from Uganda. World development, 37, 18871896.

NEGASSA, A. \& MYERS, R. J. 2007. Estimating Policy Effects on Spatial Market Efficiency: An Extension to the Parity Bounds Model. American Journal of Agricultural Economics, 89, 338-352.

OSBORNE, T. 2005. Imperfect competition in agricultural markets: evidence from Ethiopia. Journal of Development Economics, 76, 405-428.

PALASKAS, T. B. \& CROWE, T. J. 1996. Testing for price transmission with seasonally integrated producer and consumer price series from agriculture. European Review of Agricultural Economics, 23, 473-486.

PALASKAS, T. B. \& HARRISS-WHITE, B. 1993. Testing market integration: new approaches with case material from the West Bengal food economy. The Journal of Development Studies, 30, 1-57.

PARK, A., JIN, H., ROZELLE, S. \& HUANG, J. 2002. Market emergence and transition: arbitrage, transaction costs, and autarky in China's grain markets. American Journal of Agricultural Economics, 84, 67-82.

PENZHORN, N. \& ARNDT, C. 2002. Maize markets in Mozambique: testing for market integration. Agrekon, 41, 146-159. 
RASHID, S. 2004. Spatial integration of maize markets in post-liberalised Uganda. Journal of African Economies, 13, 102-133.

RASHID, S. \& MINOT, N. Are staple food markets in Africa efficient? Spatial price analyses and beyond. COMESA policy seminar on food Price Variability: Causes, Consequences, and Policy Options, Maputo, Mozambique, January, 2010. 25-26.

SANOGO, I. \& MALIKI AMADOU, M. 2010. Rice market integration and food security in Nepal: The role of cross-border trade with India. Food Policy, 35, 312-322.

SEKHAR, C. 2012. Agricultural market integration in India: An analysis of select commodities. Food Policy, 37, 309-322.

SERRA, T., ZILBERMAN, D. \& GIL, J. 2010. Price volatility in ethanol markets. European Review of Agricultural Economics, 38, 259-280.

SERRA, T., ZILBERMAN, D., GIL, J. M. \& GOODWIN, B. K. 2011. Nonlinearities in the U.S. corn-ethanol-oil-gasoline price system. Agricultural Economics, 42, 35-45.

SHARMA, A. \& SETH, N. 2012. Literature review of stock market integration: a global perspective. Qualitative Research in Financial Markets, 4, 84-122.

SOMDA, J., TOLLENS, E. \& KAMUANGA, M. 2005. Transaction costs and the marketable surplus of milk in smallholder farming systems of The Gambia. Outlook on AGRICULTURE, 34, 189-195.

TARAVANINTHORN, S. \& RABALLAND, G. 2009. Transport Prices and Costs in Africa. Washington DC: The World Bank.

THOMPSON, S. R., SUL, D. \& BOHL, M. T. 2002. Spatial market efficiency and policy regime change: seemingly unrelated error correction model estimation. American Journal of Agricultural Economics, 84, 1042-1053.

TIFFIN, R. \& DAWSON, P. J. 2000. Structural breaks, cointegration and the farm-retail price spread for lamb. Applied economics, 32, 1281-1286.

VAN CAMPENHOUT, B. 2007. Modelling trends in food market integration: Method and an application to Tanzanian maize markets. Food Policy, 32, 112-127.

VON CRAMON-TAUBADEL, S. 1998. Estimating asymmetric price transmission with the error correction representation: An application to the German pork market. European Review of Agricultural Economics, 25, 1-18.

WELDESENBET, T. 2013. Asymmetric price transmission in the Slovak liquid milk market. Agricultural Economics (Zemědělská Ekonomika), 59, 512-524.

WORAKO, T. K., VAN SCHALKWYK, H. D., ALEMU, Z. G. \& AYELE, G. 2008. Producer price and price transmission in a deregulated Ethiopian coffee market. Agrekon, 47, 492-508.

ZANIAS, G. P. 1999. Seasonality and spatial integration in agricultural (product) markets. Agricultural Economics, 20, 253-262.

ZANT, W. 2012. How Is the Liberalization of Food Markets Progressing? Market Integration and Transaction Costs in Subsistence Economies. The World Bank Economic Review, $27,28-54$.

ZHOU, Z. Y., WAN, G. H. \& CHEN, L. B. 2000. Integration of rice markets: the case of southern China. Contemporary Economic Policy, 18, 95-106. 